\title{
REPERTORIO BIBLIOGRÁFICO SOBRE EL REINADO DE ISABEL II
}

\author{
ROSA MARTÍNEZ SEGARRA \\ Profesora Titular de Historia Contemporánea \\ UNED
}



Revista de Derecho Político, núm. 39, 1995, pp. 325-399

\title{
REPERTORIO BIBLIOGRÁFICO SOBRE EL REINADO DE ISABEL II
}

\author{
POR \\ ROSA MARTÍNEZ SEGARRA
}

Con el presente trabajo intentamos hacer una aportación al conocimiento de la bibliografía existente sobre el reinado de Isabel II. No obstante, hemos de indicar que el repertorio que aquí ofrecemos constituye un intento de carácter orientativo y más selectivo que exhaustivo; ha sido nuestro propósito recoger las obras más importantes sobre el periodo estudiado, teniendo como objetivo conceder mayor relevancia a las obras fechadas en el período estudiado o próximo al mismo que a otras actuales que, con carácter general, versan sobre el momento histórico tratado; no obstante, hemos incluido algunas obras actuales, que recogen aspectos especificos del tema.

Para mayor facilidad a la hora de utilizar el repertorio, hemos clasificado el mismo en varios apartados; cada uno de ellos recoge los diversos aspectos que conforman la sociedad española de la época, aunque hemos incidido especialmente en aquellos estudios que versan sobre aspectos jurídico-políticos e institucionales, así como aquellas obras que reflejan el pensamiento filosófico y político del momento histórico tratado. En suma, nuestro deseo ha sido ofrecer una bibliografía que enmarque la sociedad española en los aspectos antes indicados, en uno de los más importantes momentos de nuestra historia constitucional.

Los apartados en que hemos dividido el trabajo son:

1. Obras generales: Hemos indicado en este apartado, fundamentalmente, estudios que versan sobre la historia social, política y económica.

2. Economí: Hemos dividido este apartado en dos puntos: uno que recoge trabajos sobre Agricultura $e$ industria y el otro re- 
ferente a los que tratan sobre la Desamortización, ya que nos ha parecido conveniente, dada la importancia del volumen de obras sobre estos temas.

3. Cultura: Hemos resaltado aquí tres puntos: Literatura, Pensamiento y Educación. En este apartado hemos incluido solamente aquellas obras que, de forma directa o indirecta, reflejan la organización social, estructura de la sociedad y aspectos culturales básicos para comprender el proceso de cambio social y político que operaba en la sociedad española del momento.

4. Prensa: En este apartado hemos incluido solamente aquellos sectores de la prensa que más trascendencia tuvieron en el desarrollo de los acontecimientos, así como otros que, de carácter general, trataron sobre la prensa existente en el período.

5. Constitucionalismo: Hemos dejado constancia aquí de aquellos títulos clásicos aparecidos en el período, o próximos a él, que versan o recogen algún aspecto planteado en el mismo, así como obras pertenecientes al campo de la historia constitucional y parlamentaria.

6. RÉGIMEN POLITICO: Hemos dividido este apartado en tres puntos: 1) Monografías referentes al reinado de Isabel II, que recoge los trabajos específicos que resaltan la situación de la Corona durante el período tratado; 2) Gobierno. Trata de trabajos específicos sobre la acción del Gobierno y su relación con otras instituciones del Estado; 3) Cortes. Trata sobre trabajos referidos a la actuación y funcionamiento de las Cortes, así como su relación con otras instituciones.

7. Fuerzas sociales y politicas: Hemos destacado en este apartado cinco puntos, tratando el primero sobre las fuerzas políticas que actuaron dentro del régimen político, y el segundo y tercero sobre aquellas fuerzas políticas y sociales que no se integraron en el mismo. Los puntos cuarto y quinto se refieren a instituciones que jugaron un importante papel durante todo el período.

8. Estudios REgIOnALES: Este último apartado recoge trabajos específicos sobre diferentes regiones.

Con todo ello hemos pretendido proporcionar un material de trabajo que esperamos sea útil para acercarse al conocimiento de las publicaciones sobre los distintos aspectos que configuran el reinado de Isabel II. 


\section{OBRAS GENERALES}

Aguado Bleye, P.: Compendio de Historia de España, Espasa-Calpe, Madrid, 1933.

Aguado, E.: Del siglo XVIII a nuestros días, Madrid, 1972.

Alcalá Galiano: Historia de España desde los tiempos primitivos hasta la mayoría de edad de Isabel II, Madrid, 1846.

Altamira y Crevea, R.: "Direcciones fundamentales de la historia de España en el siglo XIX», en Anales de la Universidad de Valencia, año III, cuad. 18 , págs. 93-132.

Arвor: Historia de España, estudios publicados en la revista Arbor, Madrid, 1953.

Artola Gallego, M.: Antiguo Régimen y revolución liberal, Ariel, Barcelona, 1978.

- La burguesía revolucionaria (1808-1869), Alianza Ed. Alfaguara, Madrid, 1973.

- Los origenes de la España contemporánea, Instituto de Estudios Políticos, Madrid, 1959.

- Textos fundamentales para la historia de España, Revista de Occidente, Madrid, 1973.

Aunós Pérez: Itinerario histórico de la España contemporánea, Ed. Bosch, Barcelona, 1940.

Azcárate, Pablo de: "Efemérides del siglo XIX", en Boletín de la Real Academia de la Historia, CLX, núm. 2, Madrid, 1967, págs. 223-239.

BALlesteros Y BeRETtA: Historiā de España y su influencia en la historia universal, Salvat, Barcelona, 1963.

Baumgarten, Hermann: Geschichte Spanies vom Amsbruch der Froanzövischen Revolution bis auf unser Tage, Leipzig. S. Hirzel, 1865-1871.

Beneyto: Historia social de España y de Hispanoamérica, Aguilar, Madrid, 1973.

Blanco González, Manuel: Memoria y triunfo, Gredos, Madrid, 1970.

Bozal, Valeriano: La ilustración gráfica del siglo XIX en España, Madrid (comunicación), 1971. 
Bruguera, Fdo. G.: Histoire contemporaine d'Espagne, Ophrys (avec la concours du Centre National de la Recherche Scientifique), París, 1953.

Bullón de Mendoza, Alfonso: Bravo Murillo y su significación en la política española, Madrid, 1950, Rec. M. ํㅡ. Doreno Box, "Jerónimo Zurita" II (1951), 183-184.

Burgo, Jaime del: "Fuentes de la historia de España», en Bibliografía de las guerras carlistas $y$ de las luchas políticas del siglo XIX. Antecedentes desde 1814 y apéndice hasta 1936. TI: A-E, CSIC. Institución Príncipe de Viana, Pamplona, 1953.

Cacho Viu, Vicente: "Les trois Espagnes contemporaines», en La Table ronde, número 190, París, 1963.

Calero, A. M. - : Sociedad, política y cultura en la España de los siglos XIX y XX. Madrid, 1973.

CARR, Raymond: España, 1808-1939, Ed. española, rev. de J. Romero Maura, traducción de Juan Ramón Capella, Jorge Garzolini y Gabriela Osberg, Ariel, Barcelona, 1969.

Cierva y de Hoces, Ricardo de la: Historia básica de la España actual (18001974), Ed. Planeta, Barcelona, 1974.

Costa, Joaquín: Historia, política social: patria. Selección y prólogo de José García Mercadal, Ed. Aguilar, Madrid, 1961.

Delgado, Jaime: España y México en el siglo XIX, t. II: 1831-1845. Prólogo de Ciriaco Pérez Bustamante, CSIC, Inst. Gonzalo Fdez. de Oviedo, Madrid, 1953 (impreso en 1934).

Díaz llarRaza: Historia de la revolución política de España desde 1834 (s.i.) Madrid, 1846.

Díaz-Plaja, Fernando: La historia de España en sus documentos: el siglo XIX, Imp. de la E. P., Madrid, 1954.

- La vida española en el siglo XIX, Afrodisio Aguado (Talleres de Ediciones Castilla), Madrid, 1952.

Documentos del reinado de Fernando VII. V: Pedro Sainz de Andino. Escritos, Estudio preliminar y notas por F. Suárez y Ana M.a Berazaluce, Seminario de Historia Moderna de la Univ. de Navarra, Colec. histórica de la Univ. de Navarra, XX, CSIC, Pamplona, 1968.

Donoso CoRtés, Juan: "España desde 1834. Consideraciones generales", en Revista de Madrid, t. I, Madrid, 1838, págs. 3-19. 
Droz, J.; VIDALENC, J., y GENET, L.: La época contemporánea. Restauración y revoluciones (1815-1871), Eudeba, Buenos Aires, 1967.

DUVERINE, A.: Essai historique sur l'esprit de la reforme politique en Espagne, E. Duverger, París, 1840.

- El siglo XIX en España: doce estudios. Conjunto dirigido por José M. Jover Zamora, con la colaboración de varios autores, Planeta (Ensayos de Historia y Humanidades), Barcelona, 1974.

- España. Ateneo científico, literario y artístico de Madrid, La... del siglo $\mathrm{XIX}$, Colección de conferencias históricas celebradas durante el curso 1885-86, E. San Martín, Madrid, 1886-88.

- Estudios sobre la España liberal, 1808-1868, volumen preparado en la Escuela de la Historia Moderna, del I. Jerónimo Zurita, bajo la dirección de V. Palacio Atard, "Cuadernos de Historia», Anexos a la revista Hispania, 4; I. Jerónimo Zurita, C.S.I.C., Madrid, 1973.

- Examen crítico de las revoluciones de España, París, 1837.

Fernández Almagro, Melchor: "Bibliografía de Historia Contemporánea de España», en Revista de E. Políticos, LIV, núm. 82, Madrid, 1955.

- "Bibliografía de Historia Contemporánea de España. Obras españolas e hispanoamericanas", en Revista de Estudios Políticos, LVIII, núm. 90, Madrid, 1956, 389-396.

- Historia política de la España contemporánea, 2 vols., Ed. Pegaso, Madrid, 1959.

Fernández de Castro, Ignacio: De las Cortes de Cádiz al Plan de Desarrollo (1808-1966). Ensayo de interpretación política de la España contemporánea, Ed. Ruedo Ibérico, París, 1968.

Fernández de los Rios, A.: Estudio histórico de las luchas políticas de la España del siglo $X I X$, por..., 2. ${ }^{a}$ ed. refundida y aumentada ilustrada con vistas de sitios y escenas (Enrique Rubiños), Madrid, 1879-80.

FerRer, Melchor: Historia del Tradicionalismo español. Tomo XVIII, Ed. Católica Española, S. A., Sevilla, 1957.

FontANA, J.: Cambio económico y actitudes políticas en la España del S. $X I X$. Barcelona, 1973.

Garcia Barrón, Carlos: "Antonio Alcalá Galiano, diplomático decimonónicon, en Arbor, LXVII, núms. 259-260, Madrid, 1967, 5-31. 
Garcia Nieto, María del Carmen; Donezar, J.; y López Puerta, Luis: Bases documentales de la España contemporánea. 2: Moderados y progresistas, 1833-1868. Introd. "La España isabelina", por García Nieto. Guadiana de Publicaciones, Madrid, 1971.

GARRIDo, F.: La España contemporánea, sus procesos morales y materiales en el siglo XIX, 2 tomos, Barcelona, 1865.

Gil Munilla, Octavio: Historia de la evolución social española durante los siglos $X I X$ y $X X$, Public. españoles, Madrid, 1961.

Gómez, Alejandro: Los sucesos de La Granja en 1836. Apuntes para la Historia, 2. ed., M. de Rojas, Madrid, 1864.

Gutiérrez Gamero, Emilio: En defensa del siglo XIX (Ensayo). Prólogo del Duque de Maura, Librería Beltrán, Madrid, 1952.

- Historia del mundo moderno, tomo X, El cenit del poder europeo, 1830-1870. Bajo la dirección de J. Patrick Tuer Bury. Traducción de María Casamar Pérez. Dirección y revisión de la traducción española por Juan Reglá. Prólogo del tomo X por A. Eiras Roel. Ed. Ramón Sopena, S. A., Barcelona, 1971.

Hernández Girbal, Florentino: José de Salamanca, Marqués de Salamanca (el Montecristo español), Ediciones Lira, Madrid, 1963.

HERR, Richard: "La inmortalidad política de la España moderna", en $R e-$ vista de Occidente, núm. 107, Madrid, 1972, 287-312.

HuME, Martín: Historia de la España contemporánea, 1788-1898. Traducción por Edmundo González Blanco, G. L. y del Horno (s. a.), Madrid.

Jover ZAMORA, J. M.: “El siglo XIX en la historiografía española contemporánea (1939-1972)", en El siglo XIX de España, Ed. Planeta, Barcelona, 1974, 9-151.

JuREtSchKe, Hans: Vida, obra y pensamiento de Alberto Lista, Madrid, 1951.

- "Postrimerías de Fernando VII y su advenimiento del régimen liberal. Apostillas a Federico Suárez", en Razón y Fe, CLII, núm. 694, Madrid, 1955, 325-334.

LA Cierva, Ricardo de: "Una triple lección (olvidada) de la historia de España. La dialéctica de las bofetadas", en Historia y Vida, II, núm. 2, Barcelona-Madrid, 1969, 134-143. 
- La España del siglo XIX. Colección de conferencias históricas celebradas durante el curso 1885-86, tomos I y II, Librería de D. A. San Martín, Madrid, 1886.

LA Rosa, Tristán: España contemporánea. Siglo XIX, Ediciones Destino, Barcelona, 1972.

LACOMBA, J. A.: Historia social de España. Siglo XIX, Guadiana, Madrid, 1972.

López Piñero, J. M.; Garcia Ballester, Luis; y Faus Sevilla, Pilar: Medicina y sociedad en la España del siglo XIX. Madrid, 1964.

Madariaga, Salvador de: España. Ensayo de historia contemporánea, 3.․․ edición, Ed. Hermes, México, 1955; Espasa Calpe, Madrid, 1971.

Marliani, M.: Historia política de la España moderna, Barcelona, 1840. La regencia de don Baldomero Espartero y sucesos que la preparan, Madrid, 1870.

Martinez de la Rosa, Francisco: Espiritu del siglo, Biblioteca de Autores Españoles.

Martínez de Velasco, A.; Sánchez Montero, R., y Montero, F.: Manual de Historia de España. Vol. 5, S. XIX, Madrid, 1990.

Mercader Riba, Juan: El siglo XIX. Prólogo de Juan Petit. Ed. Seix Barral, S. A. (Historia de la Cultura Española), Barcelona, 1957.

Morayta, M.: Historia general de España desde los tiempos antehistóricos hasta nuestros días, Madrid, 1894.

MúGICA, José: "D. Claudio Antón de Luzuriaga, ministro por primera vez", en Boletín de la R. S. Vascongada de Amigos del País, núms. 2-3-4, San Sebastián, 1954, 201-211.

NADAL, Jordi: La población española (Siglos XVI a XX). Barcelona, 4. ed.

NúÑEz dE ARENAS, M.: L'Espagne des lumières au Romantisme. Études reunies par Robert Marrast, Centre de Recherches de l'Institut d'Études Hispaniques, París, 1964.

Oliva Marra-López, Andrés: Andrés Borrego y la política española del siglo $X I X$, Instituto de Estudios Políticos, Madrid, 1959.

Palacio Atard, V.: La España del Siglo XIX (1808-1898). Madrid, 1981.

PALmer, A. W.: Diccionario de historia moderna. Traducción de Ana María Mayench. Revisión y adaptación de Vicente Martínez Santos. Prólogo 
de Juan Reglá. Ed. Labor (Diccionario de la Nueva Colección Labor), Barcelona, 1971.

Papeles históricos de los siglos XVII al XIX, once hojas y folletos.

PAYNe, Stanley G.: "Spain», en The European Right a Historical Profile, University of California Press, Berkeley, 1965.

Pérez Camarero, Arturo: "España hace cien años», Revista de Estudios de la Vida Local. Madrid, XVIII, n. 103, 1959, 60-71.

PETRIE, sir Charles: Spain in the Modern World. The University of Nottingham Montagne Burton International Relations Lectures, 1951-52, 22 págs. Recensión de M. F. A. en Revista de Estudios Políticos, XLVI, núm. 66, 1952, 182-183. Observaciones críticas.

- The Spanish Royal house. Geoffrey Bles, London, 1958.

PIY Margall, Francisco: Historia de España en el siglo XIX, por D. Francisco Pi y Arsuaga, M. Seguí, Barcelona, 1902.

Pirala, Antonio: Historia contemporánea, Imprenta y fundición de Manuel Tello, Madrid, 1875.

- Anales de la Historia de España desde 1843 hasta el fallecimiento de D. Alfonso XII, F. González Rojas, Madrid, 1895.

Prados de la Escosura, L.: De imperio a nación, crecimiento y atraso en España (1780-1930). Alianza, Madrid, 1988.

RENOUVIN, Pierre: Histoire des relations internationales, vol. V: XIX siècle. II: De 1815 à 1871. L'Europe des nationalités et l'Eveil des nouveaux Monches. Hachette, París, 1954.

Rıco, Martín: Recuerdos de mi vida (se refiere a los años 1833-1906), Imp. Ibérica (s. a.), Madrid.

Rivas Santiago, Natalio: Narraciones contemporáneas. Páginas de mi archivo y apuntes para mis memorias. Séptima parte del Anecdotario histórico español, Ed. Nacional, Madrid, 1953.

Rodriguez Casado, Vicente: Conversaciones de historia de España, tomo II, Planeta, Barcelona, 1965.

Sánchez Agesta, Luis: "Sentido sociológico y político del siglo XIX", Revista de Estudios políticos, LI, n. 75, 1954.

SANTILLÁN, Ramón de: Memorias (1815-1856). Ed. y notas de Ana María Berazaluce. Estudio general de Navarra (Col. Histórica, núm. 3), Pamplona, 1960. 
Seco Serrano, Carlos: Historia de España, tomo IV: Época contemporánea, I. Gallach, Barcelona, 1962.

- Sociedad, literatura y política en la España del S. XIX. Madrid-BarceIona, 1973.

SeVILla Andrés, Diego: Historia política de España (1800-1967), Editora Nacional, 1968.

Siles Salinas, Jorge: Las dos fuentes de la revolución contemporánea. U. Nac. de Lugo (Fac. F. y Letras), I. de Historia, Mendoza, 1959.

Sobrequés VIDAL, Santiago: "Le retard de l'Espagne et du Portugal au XIX siècle", en Information Historique, XXVI, núm. 1, París, 1964.

SuÁrez, Federico: "La crisis política del Antiguo Régimen en España (1800-1840)", en I. H. E., núm. 804 y 5.307. Rec. Nicolás S. Albornoz en Cuadernos de Historia de España, XIX, 1953, 189-190.

- "Las "Memorias" de Ramón de Santillán y su valor en la historiografía del siglo XIX", en Revista de Estudios Políticos, LXVI, núm. 107, Madrid, 1959-60.

— El fin del Antiguo Régimen en España, 1958.

- "El régimen liberal español», en el Boletín de la Universidad de Santiago de Compostela, 1950.

Taxonera, Luciano de: González Bravo y su tiempo (1811-1871), Ed. Juventud, Barcelona, 1941.

TERÁN, Manuel de: «La inmigración política española en el Centro de Aquitania en el siglo XIX", Estudios Geográficos, Madrid, XX, n. 5, 19591960.

TERRÓN, Eloy: Sociedad e ideología en los orígenes de la España contemporánea. Barcelona, 1969.

TUÑón DE LARA, M.: Estudios sobre el siglo XIX español, 3. a ed., Siglo XXI, Madrid, 1973.

- La España del siglo XIX, Club del libro español, París (imp. Valencia), 1961. Ed. en España en Ed. Laia, Barcelona, 1974.

- "L'histoire contemporaine de l'Espagne», en Pensée, núm. 64, París, 1935, 120-122. 
Tuñón de LARA, Manuel, y otros: Historia de España. Tomo 8, Revolución Burguesa, Oligarquía y Constitucionalismo (1834-1923), Barcelona, 1981.

Ubieto, Reglá, Jover y Seco: Introducción a la Historia de España, Teide, Barcelona, 1967.

Valera, Juan: Continuación de la Historia General de España comentada por Lafuente, Barcelona, 1887-1890.

YLLÁN CALDERón, Esperanza: "Un proyecto de cesión a Francia de las Islas Filipinas (1839)", en El siglo XIX en España, Ed. Planeta, Barcelona, 1974, 253-283.

Zabala y Lera, Pío: España bajo los Borbones, Ed. Labor, Barcelona, 1955.

\section{ECONOMIA}

\subsection{Agricultura e industria}

Abadal Montal, Joaquín: "Análisis de la interrelación entre desarrollo agrícola e industrial en el período 1843-1868", en Cuadernos de Historia Económica de Cataluña, I, Barcelona, 1969, 201-204.

Álvarez Gendín, Sabino: "Un folleto interesante de Flórez Estrada”, en Boletín de I. E. Asturianos, VIII, núm. 21, Oviedo, 1954, 111-120.

ANES Álvarez, Gonzalo: "La agricultura española desde comienzos del siglo XIX hasta 1868: algunos problemas", en Ensayos sobre la economía española a mediados del siglo XIX, Servicio de Estudios del Banco de España, Ed. Ariel, Madrid, 1970, 235-263.

- "Las inversiones extranjeras en España de 1855 a 1880 ", en Ensayos sobre la economía española a mediados del siglo XIX, realizados en el Servicio de Estudios del B. de España.

ARTAL, Francisco: "Vers una política económica nacionalista burgesa (1840-1913)", en Economia crítica: una perspectiva catalana, Ed. 62 (Col. Llibres a l'Abast, 106), Barcelona, 1972, 269-298.

Bahamonde Magro, A.: El horizonte económico de la burguesía isabelina, Madrid, 1856-1866. Madrid, 1981. 
BAIROCH, Paul: "Niveaux de developpement economique de 1810 à 1910", Annales ESC, 1965, n. 6, pp. 1091-1127.

Bajos Fernández, Manuel: "Centenario de la llegada del ferrocarril por primera vez a Burgos», Boletín de la Institución Fernán González, Burgos, XIV, n. 152, 1960.

- Bilbao, plaza financiera en 1960. Edic. patrocinada por la Excma. Diputación de Vizcaya y el B. de Bilbao, Bilbao, 1960.

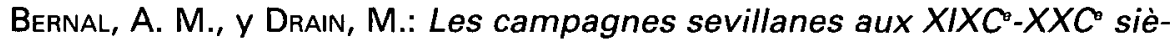
cles renovation ou stagnation, Publications de la Casa de Velázquez, Madrid, 1975.

- La propiedad de la tierra y las luchas agrarias andaluzas. Barcelona, 1974.

Blasco de Cacho, Antonio: Ante el Centenario del ferrocarril Madrid-Zaragoza. Zaragoza, n. 3, 1957.

BOnet RAmón, Francisco: «Progresión legislativa y directrices del Derecho agrario en España", en Revista General de Legislación y Jurisprudencia, XXV, 1953, 173-229.

Broder, Albert: "Les investissements étrangers en Espagne au XIXè siècle, methodologie et quantification", Revue d'Histoire Economique et Sociale (1976).

Carrera Pujal, Jaime: La economía en Cataluña en el siglo XIX. La cuestión arancelaria. II: Agricultura, artesania e industria. III: Comercio, moneda, banca, bolsa y tributos. IV: Marina mercante, puertos, carreteras y ferrocarriles, Bosch, Casa Editorial, Barcelona, 1961, 4 vols.

Casares Alonso, Aníbal: Estudio histórico-económico de las construcciones ferroviarias españolas en el siglo $X I X$, Instituto lberoamericano de Desarrollo Económico, Madrid, 1973.

CASARIEgo, J. E.: El marqués de Sargadelos a los comienzos del industrialismo capitalista en España. Oviedo, 1950.

Castedo y Hernández de Padilla, J. A.: Referencias históricas y comentarios sobre la economía arancelaria española, Imprenta Sáez, Madrid, 1958.

Castejón Montijano, R.: Génesis y desarrollo de una sociedad mercantil e industrial en Andalucia: la Casa Carbonell de Córdoba (1866-1918). Pub. del Monte de Piedad de Ahorros de Córdoba, 1977. 
Castillo, Alberto de: La Maquinista Terrestre y Martítima, personaje histórico (1855-1955). Barcelona, 1955.

Comercio EXterior de España desde 1850, Boletín minero e industrial, Bilbao, XXXIII, n.ำ 7, 1954.

CORTADA, James W.: "British consular Reports on Economic and Political Movements in Cataluña, 1842-1875", en Cuadernos de Historia Económica de Cataluña, X, Barcelona, 1973, 149-198.

COSTA, Joaquín: «El pueblo y la propiedad territorial. Ideas revolucionarias de antiguos gubernamentales", en Revista de Trabajo, núm. 5, Madrid, 1964.

Curet, Francesc, La Jamancia, 1842-43. Rafael Dalmau Editor (Episodis de la Historia, 16), Barcelona, 1961.

Fernández Pinedo, E. I., y Hernández Marco, L.: Industrialización y nacionalismo. Barcelona, 1985.

Fernández Pulgar, C., y Anes, Rafael: La creación de la peseta en la evolución del sistema monetario de 1847 a 1868. Publ. en "Ensayos sobre la economía española a mediados del siglo XIX", ed. por el B. de España.

flórez Estrada, Álvaro: Obras... Estudio preliminar y edición de M. Artola Gallego y Luis Alfonso Martínez Cachero, Atlas (Estades), Madrid, 1958.

Fontana I LAzaro, Josep: Aribau i la industria cotonera a Catalunya, Ed. Rafael Dalmau (Episodis de la Historia, 44), Barcelona, 1963.

- Cambio económico y actitudes políticas en la España del siglo XIX, Ed. Ariel (Col. "Ariel quincenal»), Esplugas de Llobregat, 1973.

Fornies BAIgorRi, Ascensión: La vida comercial española, 1829-1885. Instituciones, doctrina y legislación comercial, Institución Fernando el Católico, Zaragoza,

Ganga Argüelles, José: Elementos de la ciencia de la Hacienda. Prólogo de Fabián Estapé. Instituto de Estudios Fiscales, Ministerio de Hacienda, Madrid, 1962.

Garcia Delgado, J. L.: Orígenes y desarrollo del capitalismo en España. Notas Críticas. Madrid, 1975.

Garcia Hernández, José: "La Hacienda estatal y hacienda local», en Revista de Estudios de la Vida Local, XIII, núm. 73, 3-50. 
GarRabou, Ramón: "Las transformaciones agrarias durante los siglos XIX y XX", en Agricultura, comercio colonial y crecimiento económico en la España contemporánea, Ed. Ariel (Col. Ariel Historia, núm. 3), Esplugas de Llobregat, 1974, 206-229.

Garrabou, R., y Sanz, J. (Compiladores): Historia agraria de la España contemporánea. Ed. Crítica, Barcelona, 1985.

GILLE, Bertrand: Capitaux français et chemins de fer européens, 18521857 , en "Resumes des communications, $\mathrm{Xl}^{\circ}$ Congres International de Sciences Historiques, agosto, 1960.

González Portillo: La formación de la sociedad capitalista en el País Vasco. S. Sebastián, 1981.

InIesta Onega, Antonio: "Patricio de la Escosura, "el hombre de las transformaciones" ", en Revista de la Literatura, IX, núms. 17-18, Madrid, 1956.

El Instituto Agrícola Catalán de San Isidro un siglo atrás, Revista del Instituto Agrícola Catalán de S. Isidro, CIII (1954), n.ำ2, 38-40.

IZARD, Miguel: Inversión de capitales en la primera etapa de la industrialización catalana. Catálogos y estudios complementarios de la exposición documental y bibliografía sobre la industria textil catalana, Tarrasa, 1973,16 págs. s/n.

JUtglar, Antonio: La era industrial en España (Aproximación de la historia social de la España contemporánea), Ed. Nova Terra, Barcelona, 1963.

LLuCH, Ernest: "Jaume Andreu y la difusión de la economía", en Revista de Occidente, núm. 83, Madrid, 1970, 231-235.

LACOMBA, J. A.: Introducción a la historia económica de la España contemporánea, 2.․ ed., Ed. Guadiana, Madrid, 1972.

- "Los principios financieros en las leyes constitucionales españolas (Del Estatuto de Bayona a la Constitución de 1857)", en Cuadernos bibliográficos de Hacienda Pública, II, núm. 5, Deusto (Bilbao), 1959.

Martinez Cachero, Luis A.: Álvaro Flórez Estrada. Su vida, su obra política y sus ideas económicas, Ins. de Estudios Asturianos, Oviedo, 1961.

MoREAU DE Jones: Estadística de España, traducida y adicionada por Pascual Madoz, Madrid, 1835. 
Moral RuIz, J. del: La agricultura española a mediados del siglo XIX. Madrid, 1979.

Mutiloa PozA, José María: La desamortización eclesiástica en Navarra. Aspectos de la desamortización previo el estudio... del patrimonio de la Iglesia en Navarra, Universidad de Navarra, Pamplona, 1972.

NADAL, Jordi, y RiBAS, Enric: «Una empresa cotonera catalana: la fábrica de la Rambla de Vilanova, 1840-1861", en Industralitzación i ruptura social. Recerques, Ed. Ariel (Hacienda, Economía, Cultura, 3), Esplugas de Llobregat, 1974, 47-81.

NADAL, J., y CARRERAS, A. (eds.): Pautas regionales de la industrialización española siglos XIX y XX. Barcelona, 1990.

NADAL, J:: Los comienzos de la industrialización económica española (1832-1868): la industria siderúrgica. Editado por el B. de España, Madrid, 1970.

NADAL, Jordi: El fracaso de la revolución industrial en España, 1814-1913. Barcelona, 1975.

- «Industrialización y desindustrialización del sureste español, 18171913", en Moneda y Crédito, n.o 120, marzo, 1972.

NADAL, Jorge: "La economía española (1839-1931)", en Banco de España. Una historia económica. Presentación de M. Navarro Rubio. Servicio de Estudios del Banco de España, Madrid, 1970, 315-417.

- "Los comienzos de la industrialización española (1832-1868). La industria siderúrgica», en Ensayos sobre la economía española a mediados del siglo XIX (I. H. E., núm. 82809), 203-234.

Nadal Farreras, Joaquín: Comercio exterior y subdesarrollo. La política comercial española y su incidencia en las relaciones económicas hispano-británicas de 1772 a 1914. Tesis doctoral, Barcelona, 1976.

Notas para la historia financiera de España. Reproducidas en la «Estadística de los presupuestos generales del Estado y de los resultados que ha ofrecido su liquidación", vol. I, años 1850 a 1890-91.

Pérez-Agote y Poveda, José María: "Origenes del capitalismo en Vizcaya", en Boletín de Estudios Económicos, VIII, núm. 28, Deusto, 1953, 23-48.

Pérez Moreda, V., y Reher, D. S. (eds.): Demografía histórica en España. Ed. El Arquero, Madrid, 1989. 
Plaza Prieto, Juan: «El desarrollo del comercio exterior español desde principios del siglo XIX a la actualidad", Revista de Economia Política, VI, n.․․ 2, Madrid, 1955.

Ramón de San Pedro, J. M.: “De la historia económica de España y de la pequeña historia de quienes la hicieron", en Punta Europa, I, núm. 9, Madrid, 1956.

- Don Gaspar de Remisa y Miarons, marqués de Remisa. Esbozo de la biografía de un banquero catalán en el Madrid isabelino y bosquejo del ambiente financiero de aquella época. Introducción del conde de Ruiseñada. Publicación del Servicio del Banco Atlántico, Barcelona, 1953.

- Don José Xifré Casas, industrial, naviero, comerciante, banquero y benefactor. Historia de un indiano catalán (1777-1856). Prólogo de Juan Claudio Güell y Churruca. Banco Atlántico, Servicio de Estudios, Madrid, 1956.

Reflexiones sobre la continuación o supresión o modificación del diezmo, por D. J. J. B., M. de Burgos, Madrid, 1838.

Robledo Hernández, R.: La renta de la tierra en Castilla la Vieja y León (1863-1913). Ed. Banco de España, Madrid, 1980.

Rodriguez, J. J.: "Aportación al estudio de los reales de a dos. Las pesetas de Isabel II (1833-1868)", Numisma, VII, n.ํ25, Madrid, 1957.

RomAnones, conde de: Salamanca, conquistador de riqueza, gran señor, Espasa Calpe, S. A. (Col. Austral, núm. 316), Madrid, 1962.

Romero de Solis, P.: La población española en los S. XVIII y XIX. Madrid, 1973.

URIA RIU, Juan: "Flórez Estrada en París (1830-34)", en Archivum, núm. 1, Oviedo, 1955, 39-76.

Sánchez Albornoz, Nicolás: "Innovación técnica y resistencia gremial. El vapor en Valencia en 1842", en Cuadernos de Historia de España, XXXIX-XL, Buenos Aires, 1964, 365-369.

- La crisis de subsistencias de España en el siglo XIX, Fac. de Filosofía y Letras, I. de Investigaciones Históricas (Serie C, Estudios y Monografias, núm. 1), Rosario (Argentina), 1963.

- "Los bancos y las sociedades de crédito en provincias: 1856-1868", en Moneda y Crédito, 104, marzo, 1968, pp. 31-68. 
- "La crisis de 1866 en Barcelona (Notas para un estudio)", en Homenaje a $D$. Ramón Carande. Sociedad de Estudios y Publicaciones, Vol. II, Madrid, 1963.

- Las crisis de subsistencias en España en el siglo XIX. Rosario, 1963.

- "En Espagne, au XIXè siècle: géographie des prix», en Melange d'histoire économique et sociale en hommage au professeur Anthony Babel, Ginebra, 1961.

SÁnChez Agesta, Luis: "Caballero y la politica agraria del siglo XIX", en Boletín del Centro de Estudios Sociales de la Santa Cruz del Valle de los Caídos, número 2, Madrid, 1964.

SÁNCHEZ JIMÉnEZ, José: "Contribución a la historia rural de España: un pueblo de la serranía de Ronda", en El siglo XIX en España, Planeta, Barcelona, 1974, 285-301.

SANROMÁ, José María: "La Jamancia. Revuelta barcelonesa contra el libre cambio y ensayo de la revolución social», en Historia y Vida, II, núm. 14, Barcelona-Madrid, 1969.

Sanz Serrano, A.: Resumen histórico de la Estadística en España. Madrid, 1956.

SARDÁ, Juan: La política monetaria y las fluctuaciones de la economia española en el siglo XIX. Madrid, 1948, reed. Barcelona, 1970.

SMITH, Roberts S.: "Aspectos del libre comercio y proteccionismo en la economía española, 1800-1850", en Annuario Humanitas (Centro de Estudios Humanísticos), Univ. de Nuevo León, 1967, 636-650.

Tallada Pauli, J. M.: Historia de las Finanzas españolas en el siglo XIX. Madrid, 1944.

Toledano, Carlos: "Junta de Agricultura de 1849", publ. en Estudios de Historia Contemporánea, editados por V. Palacio Atard, Madrid, 1976.

ToRrellá NiUBo, Francisco: "Factores psicosociales en nuestra industria textil (siglos XIX-XX)", en Boletín de la Cámara Oficial de Comercio e Industria de Tarrasa, LXXXIII, núm. 673, 3 p.s.n.; núm. 677, 4 p.s.n.; núm. 678, 3 p.s.n.; Tarrasa, 1969.

Tortella Casares, Gabriel: Los orígenes del capitalismo en España. Banco. Industria y Ferrocarriles en el siglo XIX. Madrid, 1973.

- "El principio de responsabilidad limitada y el desarrollo industrial de España: 1829-1869», en Moneda y Crédito, núm. 104, Madrid, 1968, 69-84. 
- «El Banco de España entre 1829-1929. La formación de un banco central», en Banco de España. Una historia económica, Servicio de Estudios del Banco de España, Madrid, 1970, 261-313.

VÁzQUez de Prada, Valentín: "Consideraciones a cien años, fecha sobre una ruidosa polémica: proteccionistas frente a librecambistas", en Atlántida, VI, núm. 36, Madrid, 1968, 589-599.

- «El proceso de industrialización en España (siglo XIX)», en L'industrialisation en Europe au $X I X^{\circ}$ siècle. Cartographie et typologie. Lyon, 7-10 October 1970. Centre Nationale de la Recherche Scientifique (Colloques Internationaux, Sciences Humaines), 335-346.

VICENS VIVES, Jaime: "Coyuntura económica y reformismo burgués. Dos factores en la evolución de la España del Antiguo Régimen", en Estudios de Historia Moderna, IV, 1954, 349-391.

- "La mentalidad de la burguesía catalana en la primera mitad del siglo XIX", en X Congreso Internazionale di Scienza Storiche, VII, 323327.

VICENS VIVES, J., y LLoRENS, Montserrat: Industriales i politics del segle XIX, Ed. Teide (Biografies catalanes, Série histórica, XI), Barcelona, 1958.

VILA VALENTI, Juan: "El origen de la industria catalana moderna", en Estudios Geográficos, XXI, núm. 75, Madrid, 1960.

VIÑAS, Carmelo: "Tres definidores o defensores de la comunidad de empresa en la España del siglo XIX", en Anuario de Historia Económica y Social, I, Madrid, 1968, 642-653.

Voltes Bou, Pedro: «Ensayo sobre las motivaciones económicas del fenómeno románticon, en Cuadernos de Información Económica y Sociológica, núms. 2-3, Barcelona, 1956.

- La banca barcelonesa de 1840 a 1920, Ayuntamiento de Barcelona, Instituto Municipal de Historia (Doc. de Estudios), vol. XII, Barcelona, 1963.

- "Tipificación del grupo financiero como grupo de presión", en Revista del Instituto de Ciencias Sociales, núm. 5, Barcelona, 1965.

WEISS, F.: Historia general de los ferrocarriles españoles, 1830-1941. Madrid, 1967.

- Origen y desarrollo de los ferrocarriles aragoneses. Zaragoza, n. 3 , 1965. 


\subsection{Desamortización}

Álvarez Mendizábal, Juan: Memoria sobre la reforma del sistema actual de diezmos, leida a las Cortes, Miguel de Burgos, Madrid, 1837.

ANES ÁlvAREz, Gonzalo: "La crítica de un programa de los ilustrados en vísperas de la desamortización", en Revista de Occidente, VI, 2." época, núm. 65, Madrid, 1968, 189-198.

Antequera, T. M.: La desamortización eclesiástica considerada en sus diferentes aspectos y relaciones, Imp. de A. Pérez Dubrull, Madrid, 1885.

Cuenca ToRiBio, José Manuel: "La desarticulación de la Iglesia española del Antiguo Régimen (1833-1840)", en Hispania Sacra, XX, núm. 39, Barcelona-Madrid, 1967, 33-98.

Cuevas Granero, M. D.: "Fondos de Hacienda, actualmente en el Archivo del Reino relativos a la desamortización", en Primer Congreso de Historia del País Valenciano, I, Universidad de Valencia, 1973, 279-288.

Donezar Dízz de UlzurRun, Javier M.: «Datos sobre la propiedad rústica de la Iglesia navarra en época de Mendizábal», en Cuadernos de Historia Económica de Cataluña, VIII, Barcelona, 1972, 97-117.

- La desamortización de Mendizábal en Navarra, 1836-51, Ins. Jerónimo Zurita, C.S.I.C., Madrid, 1975.

Fernández Catón, José Maria: Efectos de la desamortización en la diócesis de León. San Marcos de León. Un siglo de historia, 1835-1961, Archivo Histórico Diocesano, León, 1961.

Folch, Artemi: Aspectes de la desamortizació (segle XIX), Rafael Delmau editor (Episodis de la Historia, 176), Barcelona, 1973.

Fort Cogul, Eufemia: "Las desamortizaciones del siglo $\mathrm{XIX}$ y su repercusión en Santes Creus", en Studia Monastica, XIII, núm. 1, 105-128, y XIV, núm. 1, 183-236, Montserrat, 1971.

Gómez Chaparro, Rafael: La desamortización civil en Navarra, Ed. Universidad de Navarra, Pamplona, 1967.

González Bruguera, F.: "Quelques données sur la desamortization au Campo de Calatrava (1845-1858)". Cahiers d'Histoire, Lyon, IV, n. 4, 1959.

LAZO, Alfonso: "La desamortización eclesiástica en la provincia de Sevilla: estudio de las fuentes", en Moneda y Crédito, núm. 100, Madrid, 1967, 91-103. 
Lazo Diaz, Alfonso: La desamortización de las tierras de la lglesia en la provincia de Sevilla (1835-44). Prólogo de Octavio Gil Munilla. Publ. de la Diputación Provincial de Sevilla, 1970.

López Puerta, L.: "Las ventas de bienes eclesiásticos en la provincia de Guadalajara", en Estudios sobre la España liberal, C.S.I.C., Madrid, 1973, 381-418.

Martín Martín, Teodoro: "La desamortización en la región de la Vera. Datos para un estudio de la historia económica de Extremadura", en Revista de Estudios Extremeños, XXVIII, núm. 2, Badajoz, 1972, 371-398.

Martin, Teodoro: La desamortización. Textos político-jurídicos, Ed. Narcea, S. A., Madrid, 1973.

MenÉndez y Pelayo, Marcelino: "La desamortización de los bienes de la Iglesia», en Lectura, CLX, núm. 1, México, 1964.

MerCADer I RIBA, Joan: "Incedències politico-sociales damunt la propietat monacal catalana en el primer terç del segle XIX", en Colloqui d'Historia del Monaquisme Catalá, I, Publ. de l'Arxiu Bibliografic de Santes Creus, núm. 24. Santes Creus, 1967, 183-208.

Moxó, Salvador de: La disolución del régimen señorial en España, C.S.I.C., Escuela de Historia Moderna, Madrid, 1965.

MUTILOA, J. M.: "Documentos inéditos de la desamortización en Loyola", en Letras de Deusto, XVIII, núms. 39-41, Bilbao, 1970, 447-458.

MUtiloa PozA, J. M.: "La desamortización civil en Vizcaya y las provincias vascongadas", en Estudios Vizcaínos, núm. 3, Bilbao, 1971, 15-67.

NoCHE, Diego de: Las cuentas de Mendizábal, los diezmos, la revolución y otros tratados tan graves como amenos, Madrid, 1837.

Otero Pedraya, Ramón: "Ensayo sobre la desamortización eclesiástica en tierras de Orensen, en Cuadernos de Estudios Gallegos, X, núm. 30, Santiago de Compostela, 1955, 89-110.

Polo de Bernabé y Borrás, José: Apología de la amortización eclesiástica, M. Rivadeneyra, Madrid, 1848.

Porres Martín-Cleto, J.: La desamortización del siglo XIX en Toledo, Diputación Provincial, Toledo, 1969.

Prieto Escudero, Germán: "La burguesía beneficiaria de las desamortizaciones", en Revista de Estudios Políticos, núm. 179, Madrid, 1971, 65-84. 
Quirós LinARES, Francisco: "La desamortización, factor condicionante de la estructura de la propiedad agraria en el Valle de Alcudia y Campo de Calatrava», en Estudios Geográficos, XXV, núm. 96, Madrid, 1964.

Reus Garcia: Manual de la desamortización civil y eclesiástica en las disposiciones legales publicadas hasta fin de 1861, Madrid, 1862.

Rueda, G.: La desamortización de Mendizábal y Espartero en España. Madrid, 1986.

- "Los beneficiarios del proceso desamortizador en una zona de CastiIla la Vieja (1821-1891)", publ. en Moneda y Crédito, 137, junio 1976, pp. 83-84.

Ruiz, Agustín: "La comunidad de Silos exclaustrada". III. "El despojo del Monasterion, en Yermo, IX, núm. 2, El Paular, 1971, 141-160.

- "Los exdaustrados de Silos, una "comunidad" fuera de su monasterio", en Los consejos evangélicos en la tradición monástica, en Studia Silentia, I, Abadía de Silos, 1975, 248-277.

Simón Segura, Francisco: Contribución al estudio de la desamortización en España. La desamortización de Mendizábal en la provincia de Gerona, Inst. de Estudios Fiscales, Madrid, 1969.

- Contribución al estudio de la desamortización en España. La desamortización de Mendizábal en la provincia de Madrid, Inst. de Estudios Fiscales, Madrid, 1968.

- "La desamortización de Mendizábal en la provincia de Barcelona", en Moneda y Crédito, núm. 98, Madrid, 1966, 121-141.

- La desamortización española en el siglo XIX. Ministerio de Hacienda, Instituto de Estudios Fiscales, Madrid, 1973.

TomÁs y VAliente, Francisco: "Algunos ejemplos de jurisprudencia civil y administrativa en materia de desamortización", en Agricultura, comercio colonial y crecimiento económico en la España contemporánea, Ed. Ariel, Esplugas de Llobregat, 1974, 67-89.

- El marco político de la desamortización en España, Ed. Ariel, Barcelona, 1971.

- "Planteamientos politicos de la legislación desamortizadora», en Revista Crítica de Derecho Inmobiliario, XLV, 1969, 873-961 (separata). 
Tomás y Valiente, F.; Rodríguez Flórez, I.; Borrego Bellido, F.; Casero Lambas, J. F., y Gutiérrez Sarmiento, H.: "Jurisprudencia administrativa sobre bienes sujetos a desamortización", en Actas del III Symposium de Historia de la Administración, Madrid, 1974, 35-145.

TORRENT Y FÁBREGAS, Juan: "Inventarios y enajenación de efectos del suprimido monasterio de San Feliú de Guíxols (1835-1839)", en Anales del I. de Estudios Gerundenses, XX, Gerona, 1970-71, 283-315.

VILLABONA, Pilar: La desamortización en la provincia de Murcia. Tesis Doctoral leída U. Complutense, Madrid, 1976.

ZAMORA LUCAS, Florentino: "La desamortización en la provincia de Soria. EI monasterio de Espejo, desaparecido en nuestros días", en Celtiberia, VIII, núm. 11, Soria, 1956.

\section{CULTURA}

\subsection{Literatura}

Adams, Nicholson B.: "French influence on the Madrid theater in 1837 ", en Estudios dedicados a M. Pidal, VII: I, 135-151. C.S.I.C., Patronato Marcelino Menéndez y Pelayo, Madrid, 1957.

Álamo, Néstor: «El Gabinete literario. Crónica de un siglo, 1844-1944". Aparecido en forma de folletón en el Diario de Las Palmas (1957), p. 115.

Alcalá Galiano, Antonio: Literatura española del siglo XIX. De Moratín a Rivas. Traducción, introducción y notas de Vicente Lloréns. Alianza Editorial, S. A. (El Libro de Bolsillo, núm. 170), Madrid, 1969.

Álvarez Arregul, Federico: "Larra en España y América», en Ínsula, XVII, Madrid, 1962.

Aluson Peers, E.: Historia del movimiento romántico español. Traducción del inglés por José Maria Gimeno. Biblioteca Románica Hispánica, "Tratados y Monografias", núm. 4, Madrid, 1954, 2 vols.

Antología de la novela histórica española (1830-1844). Recopilación, estudio preliminar y preámbulos de Felicidad Buendía. Aguilar, S. A., Madrid, 1963. 
Antología dels Jocs Florals. Sintesi histórica. Ed. Selecta (Biblioteca Selecta, n.․ 149), Barcelona, 1954.

ARco, Ricardo del: "Un gran literato aragonés olvidado: Braulio Foz", en Arch. de Filología Aragonesa, V, 1953, 7-103.

Artigas Sanz, Maria del Carmen: El libro romántico en España, C.S.I.C., Instituto "Miguel de Cervantes" (Colección bibliográfica, X a XIII), Madrid, 1953-1955, 3 tomos, el último 2 vols.

Auв, Max: La prosa española del siglo XIX. Prólogo, selección y notas. Tomo I: Neoclásicos y liberales, México, 1952, 318 págs.

Batista I RocA, J. M.: Els precursors de la Renaixença. 3: "El retorn dels liberals. La Junta del Principat (1835) i la Renaixença", en Ocho Conferencies sobre Catalunya, Aymá Editora, Barcelona, 1971, 109122.

BAUBY, Carles: "Discurs en el acte conmemoratiu del centenari de la restauraió dels Jocs Florals de Barcelona», Tramontane (Perpignan) XLIII, n.. 426-427, 1959, pp. 195-197.

Benitez, Rubén A.: "Introducción a la Crítica de Bécquer», Revista de la Universidad de Buenos Aires, IV, n.o 2, 1959, 199-212.

Benitez Claros, Rafael: Antonio Flórez. Una visión costumbrista del siglo $X I X$, Universidad de Santiago de Compostela, Secretariado de Publicaciones, 1955.

Bofill i Ferro, J., y Comas, Antoni: Un segle de poesía catalana, Destino, Barcelona, 1968.

BozAL, Valeriano: «El arte español del siglo XIX», en Cuadernos Hispanoamericanos, LXIX, núm. 207, Madrid, 1967, 501-505.

- "El arte popular en la España del XIX", en Cuadernos Hispanoamericanos, núm. 218, Madrid, 1968, 276-301.

Bravo-Villasante, Carmen: Una vida romántica. La Avellaneda, Editora y Distribuidora Hispano Americana («El Puente», 24), Barcelona-Buenos Aires, 1967.

Brown, Rice: Bécquer - "Gustavo Adolfo Bécquer en dos tiempos". Prólogo de V. Aleixandre, Ed. Aedos, Barcelona, 1963.

Cossio, José M. de: Cincuenta años de poesía española (1850-1900). Espasa Calpe S. A., Madrid, 1960, 2 vols. 
- "Bibliografía decimonónica: Zorrilla, la Avellaneda y Alarcón", Boletín de la Biblioteca de Menéndez Pelayo (Santander) XXXIV, n.․ 3 (1958), 262-267.

Entrambasaguas, Joaquín de: "La traducción castellana del famoso soneto de Blanco-White", Revista de Literatura, VI, n. 11-12, 1954.

Espadas Burgos, Manuel: "El misterio de "El padre Cobos" ", Revista de Literatura, VII, n.우 13-14, 1955.

Ferreras, Juan Ignacio: La novela por entregas 1840-1900, Madrid, 1972.

- El triunfo del liberalismo y la novela histórica 1830-1870. Madrid, 1976.

GAOS, Vicente: La poesía española en el siglo XIX, en Temas y problemas de la literatura española, Ed. Guadarrama, Madrid, 1959.

Martinengo, Alessandro: Para una nueva edición de Espronceda. Thesaurus, Bogotá, XIX, n.ำ 1, 1964.

MiRANDA, Soledad: Religión y clero en la gran novela española del siglo XIX. Madrid, 1982.

MONTESINOS, J. F.: Introducción a una historia de la novela en España en el siglo XIX, seguida del esbozo de una bibliografía española de traducciones de novelas (1800-1850). Ed. Castalia, Valencia, 1955.

Montoliu, Manuel: "Aribau y Cabanyes", en Cuatro etapas en la evolución de la literatura catalana moderna, Madrid, 1956.

Mоnтото, Santiago: "Cartas inéditas de Fernán Caballero", Boletín de la R. Academia Española, XLXV, n. 146, Madrid, 1955.

LISSOURGes, I. (ed.): Realismo y naturalismo en España en la segunda mitad del siglo. Ed. Antropos, Barcelona, 1988.

OCHOA, E. de: Costumbristas españoles. Ed. de Correa Calderón.

Riera y Beltrán, Joaquín: Biografía de Buenaventura Carlos Aribau, en Galería de Catalanes llustres. Biografías, vol. II.

Romero Tobar, Leonardo: "Una oda desconocida de Martínez de la Rosa". Revista de Literatura, XXI, n. 41-42, Madrid, 1962.

RUMeU de ARmAs, A.: Historia de la censura literaria gubernativa en España, Madrid, 1940.

- "Una travesura de Larra o dos dramas y una comedia a un tiempo", en Ínsula, XVII, núms. 188-189, Madrid, 1962. 
Sallence, J.: Médicos gallegos en la política y las bellas letras. Imp. "El Ideal Gallegon, La Coruña, 1958.

SÁnCHEZ de Huelva, Alfonso: "Mariano José de Larra", en Ambos Mundos, I, número 4, México, 1962.

Saro, Pilar de: "Algunos textos raros de y sobre el Duque de Rivas", Revista de Literatura, XXI, n. 41-42, Madrid, 1962.

Seco Serrano, Carlos: "De "El pobrecito hablador" a la "Colección" de 1835: Los "arrepentimientos" literarios de Figaro", en insula, XVII, núms. 188-189, Madrid, 1962.

Senabre Sempere, Ricardo: "Temas franceses en Larra», en Insula, XVII, núms. 188-189, Madrid, 1962.

Shaw, D. L.: Historia de la literatura española. Barcelona, 1974.

Simón Diez, José: «Noticia sobre los escritores del siglo XIX en los diarios de la época", en Revista de Literatura, XI, núms. 21-22, Madrid, 1957.

TASSARA Y de SANGRAN, Joaquín: "El Romanticismo en la escuela poética sevillana", en Archivo Hispalense, XXXIX, núms. 120-121, Sevilla, 1963.

TORRE, Elías: "Un inmediato antecedente de "El estudiante de Salamanca"", en Ínsula, XII, núm. 132, Madrid, 1957.

TORRE, Guillermo de: "Larra en América», en Ínsula, XVII, Madrid, 1962.

- "Larra y España», en Cuadernos, núm. 43, París, 1960, 66-72.

Torrente Fortuno, J. A.: Salamanca, bolsista romántico. Madrid, 1969.

TORRES AMAT, Félix: Memorias para ayudar a formar un diccionario crítico de los escritores catalanes y dar alguna idea de la antigua y moderna literatura de Cataluña, Barcelona, 1836 (Documentos de Cultura. Fasc. 13, Barcelona-Sueca, 1973.

TORRES, David: "El españolismo de Fígaro", en Ínsula, XVII, núms. 188189, Madrid, 1962.

UCELAY dE COL, Margarita: Españoles pintados por sí mismos (1843-44). Estudio de un género costumbrista, El Colegio de México, México, 1951.

UlLman, P. L.: "Larra y la policía", en ínsula, XVII, núm. 193, Madrid, 1962.

VARELA, José Luis: "Larra ante el poder", en ínsula, XIX, núm. 206, Madrid, 1964, págs. 1 y 7. 
- Poesía y restauración cultural de Galicia en el siglo XIX. Ed. Gredos, Madrid, 1958.

Varela Jacome, Benito: "Rosalía de Castro, novelista", en Cuadernos de Estudios Gallegos, XIV, n.․ 42, Santiago de Compostela, 1959.

Verdaguer, Jacint: Escrits inédits de... Vol. I, Ed. Barcino (Biblioteca Verdagueriana), Barcelona, 1958.

VIÑAS, C. M. F., José M. .a: "San Antonio María Claret y el Vigatanismo", Aura, III, n.․ 27, Vich, 1959, 161-165.

ZaBALA, Iris M.: Ideología y política en la novela española del siglo XIX, Ediciones Anaya, Salamanca, 1971.

\subsection{Pensamiento}

Alonso Y CASTILLO, Mariano: Refutaciones sobre la libertad de cultos en España: república, socialismo, prensa periódica sin restricciones, pueblo armado en totalidad, reducción de tributos sin mesura, causas de la tiranía, J. Reyes y Moreo, Huelva, 1855.

Azcárate, Pablo de: "Revisión de Fernando de Castro", en Revista de Occidente, núm. 104, Madrid, 1971, págs. 220-226.

Balmes, J.: Escritos políticos de D..., Colección completa, corregida y ordenada por el autor. Observaciones sociales, políticas y económicas sobre los bienes del clero, Vich I. Valls, 1840.

- Consideraciones posibles sobre la situación de España, en Obras completas, t. VI.

"Clarin" patriótico, o sea, discurso político-filosófico sobre los árboles de la iniquidad y equidad, Imp. de Juan Oliveres, Barcelona, 1837.

BATLloRI, S. I., Miguel: Balmes i Casanovas. Estudis biografics i doctrinals. Ed. Balmes, Barcelona, 1959.

Diaz, E., y NúÑEz-EnCABO, M.: "Julián Sanz del Río: textos inéditos (noticia y selección)", en Revista de Occidente, núm. 79, Madrid, 1969, págs. $1-18$.

Donoso CoRtés, Juan: Los errores de nuestro tiempo, Henche, Suministros a Talleres Gráficos, Madrid, 1955. 
Fernández Carvajal, Rodrigo: "El pensamiento español en el siglo XIX", en Historia de las literaturas hispánicas, V, Ed. Barcelona, Barcelona, 1955.

Fraga Iribarne, Manuel: Balmes, fundador de la sociología política en España, Vich, 1955.

Gabino Herrero, Santiago: Donoso Cortés y su teoría política, Imp. de la Excma. Diputación Provincial de Badajoz, Badajoz, 1957.

Graham, John T.: Donoso Cortés, utopian romanticist and political realist, University of Missouri Press, Columbia, 1974.

- Donoso Cortés on liberalism, Univ. Saint Louis, 1957.

ItURmend Bañales, A.: Balmes sacerdote: su magisterio politico visto por un seglar, Pub. del Ayuntamiento, Vich, 1970.

JuTglar, Antoni: Ideologias y clases en la España contemporánea (18081874), I, Cuadernos para el Diálogo, S. A., Divulgación Universitaria (Cuestiones Españolas, núm. 14), Madrid, 1968.

La Orden, Ernesto: Jaime Balmes, político, Labor (Galve), Barcelona, 1942.

Maragall, Jordi: «Entorn del pensament social de Balmes», en Serra d'Or, X, número 108, Barcelona, 1968, págs. 29-31.

Maravall, José Antonio: “El pensamiento político español a comienzos del siglo XIX: Martínez Marín", en Revista de Estudios Políticos, núm. 81, Madrid, 1955.

MAResCA, M.: "Aportación a una bibliografía del krausismo español", en Anales de la cátedra Francisco Suárez, núm. 11, Granada, 1971, págs. 281-336.

Marti, C.; LlorÉns, M., y G.. a Nieto, J. N.: «El sindicalismo católico en Españan, en Historia del movimiento obrero cristiano, Estela, S. A., ed. Nova Terra, Barcelona, 1964.

Mendoza S. I., Juan de Dios: Bibliografía balmesiana. Ediciones y estudios, Balmes (Biblioteca Histórica de Balmes), serie II, vol. XXIV, Barcelona, 1961.

Murillo Ferrol, Fernando: Estudios de Sociología Política. Ed. Tecnos, Madrid, 1963.

Nieto Cumplido, Manuel: «Primeros estudios filosoficos de Julián Sanz del Río", en Bol. de la Real Academia de Córdoba de Ciencias, Bellas Letras y Nobles Artes, XXXIX, núm. 90 (1970 [1973]), 135-148. 
Oliva MARRA-López, Andrés: "Andrés Borrego, político malagueño del siglo XIX», en Revista de Estudios Políticos, LXI, núm. 95, Madrid, 1957, págs. 109-147.

Oller I Romeu, J. M.:- «Balmes i el moviment obrer a Catalunya del 1840 al 1843", en Serra d'Or, X, núm. 106, Barcelona, 1968, págs. 23-26.

- Introducció del socialisme utópic a Catalunya (1835-1837), Edicions 62 (Antología Catalana, 53), Barcelona, 1969.

- Milá de la Roca, escriptor i activista contrarrevolucionari (1840-1843), Rafael Dalmau editor (Episodis de la História, 174-175), Barcelona, 1973.

Osorio, Alberto: "Exposición del krausismo hispano", en Lotería, V, núm. 168, Panamá, 1968, págs. 36-38.

Pastor Díaz, Nicomedes: Obras completas. Estudio preliminar y edición de J. M. Castro y Calvo, Atlas (Biblioteca de Autores Españoles), Madrid, 1969.

Peñalver Simó, Patricio: "La filosofía europea (1830-1870) y Concilio Vaticano |", en Scripta Theologica, núm. 2, Pamplona, 1970, págs. 39-60.

Portús, Rafael: "El poder civil en los escritos de Balmes", en Analecta sacra Tarraconensia, XXXVI, núm. 1, Barcelona, 1963 [1964].

Prieto Escudero, Germán: "El estado del pensamiento social en la España decimonónica", en Revista de Estudios Políticos, núm. 149, Madrid, 1966, págs. 47-65.

- "El pensamiento político del doctrinarismo neocatólico español», en Revista de Estudios Políticos, núm. 158, Madrid, 1968, págs. 43-58.

Rodríguez-Moñino, Antonio: Correspondencia de D. Bartolomé José Gallardo. Cuarenta cartas inéditas que publica..., Imp. de la Diputación Provincial, Badajoz, 1960.

SAINz de Robles, Federico Carlos: Jaime Balmes. Estudio y antología, Compañía Bibliográfica Española, S. A. (Col. "Un autor en un libro", núm. 18), Madrid, 1964.

Serrano Villafañé, Emilio: "Obras completas de Donoso Cortés (Recensión bibliográfica)", en Revista de Estudios Políticos, núm. 191, Madrid, sep.-oct. 1973.

SeVILla AndrÉs, Diego: «España y África en el pensamiento de Donoso Cortés", en África, XI, núm. 149, 1954, págs. 212-214. 
SUÁREz, Federico: Introducción a Donoso Cortés, Rialp, S. A. (Col. “Naturaleza e Historia», núm. 7), Madrid, 1964.

SuÁrez Verdaguer, F.: Donoso Cortés en el pensamiento europeo del siglo XIX, Ateneo, Madrid, 1954.

VILA Selma, José: Ideario de Manuel José de Quintana, C.S.I.C. (Inst. Miguel de Cervantes), Madrid, 1961.

Westemeyer, Djetmar: Donoso Cortés, hombre de Estado y teólogo. Presentación de Santiago Galindo Herrero, Editora Nacional (Libros de Actualidad Internacional, 30), Madrid, 1957.

YEPES del Pozo, Juan: "Concepto sociológico de la Revolución”, Journal of Inter-American Studies, II, n. 2, Gainesville, Florida, 1960.

\subsection{Educación}

Álvarez Morales, A.: Génesis de la Universidad española contemporánea. Madrid, 1972.

Garrorena Morales, Ángel: El Ateneo de Madrid y la teoría de la Monarquia liberal (1836-47), Instituto de Estudios Políticos, 1974.

Gil y Zárate, A.: De la instrucción pública en España, 3 vols., Madrid, 1854.

Guereña, J. L., y Tinna, A.: Cultura y educación populares. Siglos $X I X$ y $X X$. Madrid, UNED, Casa de Velázquez.

Lımón, T., y R. MelLizo, F.: "La Universidad en querella, 1812-1874", en La Ciudad de Dios, CLXXVIII, El Escorial, 1965, 681-696.

Ollero Tassaka, A.: Universidad y política. Tradición y secularización en el siglo XIX. Madrid, 1972.

Palomeque Torres, Antonio: Los estudios universitarios en Cataluña bajo la reacción absolutista y el triunfo liberal hasta la reforma de Pidal (18241845), Publicación de la Cátedra de Historia Universal, Dto. de Historia Contemporánea, Barcelona, 1974.

PESET, Mariano y José Luis: Gregorio Mayans y la reforma universitaria, Valencia, 1975.

- "Universidades y enseñanzas del Derecho durante las regencias de Isabel II (1833-43)", en Anuario de Historia del Derecho Español, Madrid, 1969. 
- La Universidad española, siglos XVIII y XIX. Despotismo ilustrado y revolución liberal, Madrid, 1974.

Rodriguez Sánchez, Ricardo: "Panorama educacional matritense de un decenio: 1834-1843", en Rev. de la Universidad de Madrid, XIII, n. 52, $1964,657-658$.

Rupérez, P.: La cuestión universitaria y la noche de San Daniel, Madrid, 1975.

Sánchez de la Campa, J.: La instrucción pública y la sociedad, Madrid, 1865.

Simón PALmer, M. a Carmen: La enseñanza privada seglar de grado medio en Madrid (1820-1868). Prólogo de V. Palacio Atard, Inst. de Estudios Madrileños, Madrid, 1972.

- La enseñanza privada seglar en Madrid (1820-1868). Prólogo de V. Palacio Atard, Inst. de Estudios Madrileños, CSIC, Madrid, 1972.

\section{PRENSA}

Albert Berenguer, Isidro: Bibliografía de la prensa periódica de Alicante y su provincia, Alicante, 1958.

Almuiña, Celso: La prensa periódica vallisoletana en el siglo XIX. Tesis doctoral leída en la Univ. de Valladolid, septiembre de 1976.

Altabella, José: "Nuevas aportaciones a la historia del periodismo asturiano", Boletín del Instituto de Estudios Asturianos, XIV, n. 0 39, Oviedo, $1960,65-81$.

Altabella, José, y Leal InNia, Fco.: "Faro de Vigo" y su proyección histórica. Ed. Nacional, Madrid, 1965.

AsEnJo, Antonio: La prensa madrileña a través de los siglos, Madrid, 1933.

- Boletín Oficial de la Milicia Nacional (1839).

- Boletín Oficial de la venta de Bienes Nacionales (1836...).

- Boletín Oficial de Madrid (1833-1930).

- Boletín Oficial del Comercio.

Castro, Concepción de: Andrés Borrego. Periodismo liberal conservador, 1830-46, Ed. Miguel Castellote, Madrid, 1972. 
Cubero, Dolores: "El "Semanario Popular" y sus aportaciones literarias", en Revista de Literatura, IX, núms. 19-20, Madrid, 1956.

- Diario de Sevilla.

- El Eco del Comercio.

- El Amigo de la Religión y de los hombres (1836-38).

- El Amigo de la Religión Cristiano-Católica y de la Sociedad (1838).

- El Ateneo.

- El Católico (1840), periódico religioso y social.

- El Congreso (1841), político burlesco.

- El Correo Nacional (1838-1842), diario.

- El Criticón (1835-1836), de literatura y bellas artes.

- El Duende (1836-1837).

- El Eco del Comercio (1834-1849).

- El Español (1835-1848).

- El Español (1841), revista semanal de política.

- El Hablador (1837-1838), de la Constitución.

- El Genio del Cristianismo (1839), revista católico-social.

- El Grito del Ejército (1841), militar.

- El Hablador Patriota (1841), de la Constitución.

- El Liberal.

- El Mundo (1836), diario del pueblo..

- El Nuncio de la Verdad (1838).

- El Pensamiento de la Nación (1844-1846).

- EI Siglo XIX (1837-1838).

- El Tiempo (1844), conservador.

- El Turia. 
- El Vapor.

- Fr Gerundio (1837-1842).

- El eco de la Clase Obrera (1855-1856).

- La Tribuna del Pueblo (1851).

- La Voz del Pueblo.

Eguiaź́Bal: Apunte para una historia de la legislación española sobre imprenta desde el año 1840 al presente, Madrid, 1879.

Fernández Avelló, Manuel: "Notas para una historia del periodismo ovetense", Boletín del Instituto de Estudios Asturianos, XI, n. 32, Oviedo, 1957.

Garcia Figueras, Tomás: "La prensa (periódicos y periodistas) en la Guerra de África (1859-60)", Archivos del Instituto de Estudios Africanos, XI, n. 46 , Madrid, 1958.

Gómez Aparicio, Pedro: Historia del periodismo español, desde la "Gaceta de Madrid" hasta el destronamiento de Isabel II, Ed. Nacional, Madrid, 1962.

GonzÁlez Ruiz, Nicolás: «Periodismo y literatura periodística en el siglo XIX", en Historias de las literaturas hispánicas, Ed. Barcelona, Barcelona, 1958.

- La Cruz (1842), de religión.

- La España Militar (1842), periódico dedicado al Ejército y Milicia Nacional.

- La Esperanza (1844-1872), monárquico.

- La Estrella.

- La Gaceta.

- La Revista.

- La Revista Española.

- La Voz de la Religión (1837). 
LE GENTIL, Georges: Les revues littéraires de l'Espagne pendant la première moitié du XIX siècle, Aperçu bibliographique, París, 1909.

Longares, J.: "Los periódicos en la menor edad de Isabel IIa. Intento de método", en Cuadernos de Historia Económica de Cataluña, XIV, marzo, 1976, pp. 217-252.

Madrid en sus diarios. T. I, años 1830-1844. Seminario de Bibliografía Hispánica de la Fac. de Filosofía y Letras de Madrid. Instituto de Estudios Madrileños, Madrid, 1961.

Madrid en sus diarios. T. II, años 1845-59. Ordenación y clasificación por Mercedes Agulló y Coso, Madrid, 1965.

Martínez Cachero, José Maria: "Noticia de "El Nalón", periódico de Literatura, Ciencias y Artes", en Boletín del I. de E. de Asturias, VIII, núm. 22, Oviedo, 1954, 198-217.

Martínez Olmedilla, Augusto: Periódicos de Madrid. Anecdotario. «El /mparcial", "El Liberal", "La Época", "Heraldo de Madrid", "La Correspondencia de España», Ed. Aumarol, Madrid, 1956.

- Mensajero de las Cortes.

- Revista del Progreso (1841).

- Revista Militar (1838-1840).

- Semanario Pintoresco Español (1836-1855).

- Prensa Obrera en Madrid (1855-1936). 2. Coloquio de H.․ Madrileña, Alfoz, Madrid, 1987.

SAnz y Díaz, pbro., Clementino: "La imprenta en las Escuelas Pías (18581865)", en El Libro Español, II, n.․ 23, Madrid, 1958, 692-702.

Seoane, M. a Cruz: Oratoria y periodismo en la España del siglo XIX, Madrid, 1977.

SerRa Piñar, Antonio: "El derecho de rectificación en la prensa periódica", en Anales de la Asociación Española para el Progreso de las Ciencias, XIX, núm. 4 1954, 956-961.

Simón Díaz, José: "Los clásicos españoles en la prensa diaria de Madrid (1830-1900)", en Revista de Literatura, XXIV, núms. 47-48, Madrid, 1963. 
SOleR Godes, Enric: "Els primers periódics valencians», en Publicacions dels Cursos de Llengua i Literatura valenciana de "Lo Rat Penat", 91, Valencia, 1960.

Solís, Ramón: Historia del periodismo gaditano (1800-1850), San Fernando, 1971.

TORRENT, Juan: "Ciento cincuenta años de prensa manresana", Bargas, VI, n. ${ }^{\circ}$ 64-65, Manresa, 1958.

Tuñón de Lara, M.; Elorza, A.; Pérez Ledesma, M.: Prensa y sociedad en España, 1820-36, Madrid, 1975.

VALLE-INCLÁN, Ramón M. del: "Publicaciones periodísticas... anteriores a 1895", en Nueva Revista de Filología Hispánica, VIII, núm. 1, 1954, 91 99. Rec. de José F. Montesinos.

- Veinticuatro diarios, Madrid, 1830-1900. Artículos y noticias de escritores españoles del siglo XIX. Seminarios de Bibliografía Hispánica de la Facultad de Filosofía y Letras. Prólogo de José Simón Díaz, Col. de Índices y Publicaciones Periódicas, C.S.I.C., Inst. "Miguel de Cervantes", Madrid, 1968, t. I, 1970, t. II.

Zamora LUCAS, Florentino: "El Numantino" (1841-1842). El primer periódico que se publicó en Soria", en Revista de Soria, núm. 19, Soria, 1973,2 I. s. n.

ZaVala, Iris M.: Románticos y socialistas, Prensa española del siglo XIX, Madrid, 1972.

\section{CONSTITUCIONALISMO}

Alcalá Galiano, Antonio: Lecciones de Derecho Político constitucional, Imprenta D. k. Boix, Madrid, 1843.

- Obras escogidas. Prólogo y edición de Jorge Campos, Ed. Atlas (Biblioteca de Autores Españoles de la Col. Rivadeneyra), vols. 83 y 84 , Madrid, 1955, 2 vols.

Álvarez de Morales: Historia de las Instituciones españolas (siglos XVIII$X(X)$, Madrid, 1982.

ALZAGA VILLAMIL, Óscar: "Repertorio bibliográfico sobre Derecho electoral y elecciones en España (1810-1936)", en Revista de Derecho Político, núm. 6, UNED, Madrid, 1980. 
AlLER, Domingo Enrique: Exposición elemental teórico-histórica del Derecho político, Librería de Victoriano Suárez, Madrid, 1875.

ARTOLA, Miguel: Partidos y programas políticos (1808-1936), t. I, Aguilar, Madrid, 1974.

AzCÁRATe, G. de: El régimen parlamentario en la práctica, Madrid, 1977.

BarReda, Consideraciones políticas acerca de los partidos, Madrid, 1864.

BorRego, Andrés: Estudios políticos de la Organización de los partidos en España, considerado como medio de adelantar la educación constitucional de la nación $y$ de realizar las condiciones del gobierno representativo, Madrid (P. Montero), 1855.

- Excelencias y peligros del sufragio universal, Imp. Viuda e Hijo de E. Aguado, Madrid, 1887.

- "Tentativas para restablecer el sistema constitucional", en La España del siglo XIX, Madrid, 1886.

- Historia parlamentaria de España durante el siglo XIX, A. Rodero, Madrid, 1885-86, 2 vols.

- Manual electoral para el uso de los electores de la opinión monárquico-constitucional, Imp. de la Compañia Tipográfica, Madrid, 1837.

- Historia de las Cortes de España durante el siglo XIX, 2 ts., Madrid, 1885.

Calatrava y Ogayar, Francisco: Consideraciones sobre la democracia, las constituciones políticas y el movimiento constituyente de España, 2." ed., Tipografía Gutenberg, Madrid, 1882.

Calvo Marcos, Manuel: Régimen parlamentario de España en el siglo XIX. Apuntes $y$ documentos para su historia. Partes 1.a y 2. ${ }^{\text {a }}$ El Correo, Madrid, 1883.

CASEs Méndez, José Ignacio: "La elección de 22 de septiembre de 1837", en Revista de Estudios Políticos, núm. 212, Madrid, abril 1977.

Colmeiro, Manuel: Elementos del Derecho político y administrativo en España, Librería de Ángel Calleja, Madrid, 1858.

Congreso de los Diputados: Constituciones y Reglamentos, Ramón Velasco, Madrid, 1931.

- Leyes electorales y proyectos de Ley, Imp. Hijos de J. A. Garcia, Madrid, 1906. 
- Constituciones y Leyes Fundamentales de España (1808-1947), ed. preparada por A. Padilla Serra. Prólogo de L. S. Agesta, Universidad de Granada (Archivo de Derecho Público), Granada, 1954.

- Constitución de la Monarquía española promulgada en Madrid, a 18 de junio de 1837, impresa de orden de S. M. la Reina Gobernadora, Imp. Nacional, 1837.

Cordero Torres, José M.a.: "Los asuntos exteriores en las Constitucionès y leyes fundamentales españolas", en Revista de Política Internacional, núm. 88, Madrid, 1966, 335 y 344.

Cuenca Toribio, J. M.: "El constitucionalismo en España", en Atlántida, núm. 42, Madrid, 1969, 659-665.

Derozier, Albert: "Les discussions sur la loi electorale espagnole en 1835 et en 1836: le gouvernement en échec"), en Caravelle, núm. 4, Toulouse, 1965.

Domingo de Morato, D. R.: Estudios de ampliación de la historia de los Códigos españoles (s.i.), Valladolid, 1856.

Duverine, A.: Cuadro histórico de los abusos y espíritu de reforma política en España, Boix Edt., 1840.

España, Constituciones y Reglamentos, Imp. de S. A. García, Madrid, 1906.

Esteban, Jorge de: Constituciones españolas y extranjeras, Taurus, Madrid, 1977.

Farias Garcia, Pedro: Breve historia constitucional de España (de la Corte de Bayona a la Ley Orgánica), Universidad de Murcia, 1969.

Fernández Almagro: "Las Cortes del siglo XIX y la práctica electoral", en Revista de Estudios Políticos, Madrid. 1943.

- Orígenes del régimen constitucional en España, Barcelona, 1976.

Fernández Martí, M.: Derecho parlamentario español, 3 tomos, Madrid, 1885.

Fontans, J. M.: Destino y Constituciones de España, Madrid, 1945.

Galiano Herrero, Santiago: "Experiencia constitucional y monarquía tradicional, reflexiones sobre un libro nuevo", en Punta Europea, I, núm. 3 Madrid, 1956, 122-132. 
García Venero, M.: Historia del parlamentarismo español, Madrid, 1954.

Gibert, Rafael: Textos jurídicos españoles, Ed. Gómez, Pamplona, 1954.

GiL y Robles, Enrique: El absolutismo y la democracia, Imp. Católica Salmantina, Salamanca, 1892.

- Tratado de Derecho político, Imp. Católica Salmantina, Salamanca, 1899.

Gobierno y las Cortes del Estado: Materiales para su historia, Imp. de Yanes, Madrid, 1837.

Guzmán, Eduardo de: España entre las dictaduras y la democracia, Ed. Tesoro, Madrid, 1967.

Hostos, Eugenio M. de: Lecciones de Derecho constitucional, Librería Paul Ollardorff, París, 1908.

IglesIAS, C.: Las Cortes españolas, pasado, presente y futuro, Madrid, 1973. Índice cronológico de legislación estadística: Años 1813-1956, Presidencia de Gobierno, INE, Madrid, 1956.

JimÉNEZ JIMÉNEZ, M. a Desamparados: «Elecciones municipales de 1835 en Zaragoza", en Actas del III Symposium de Historia de la Administración, Inst. de Estudios Administrativos, Madrid, 1974, 757-774.

Jover ZAMORA, J. M.: "Situación social y poder político en la España de Isabel Il", en Historia social de España del siglo XIX, Ed. Guadiana, Madrid, 1972, 243-308.

- "Sociedad y Estado en tiempo del Estatuto Real", en Revista Internacional de Sociología, núms. 107-108, Madrid, 1969, 45-71.

Las elecciones. Coloquio a la plebe por un labriego, Imp. Luis Cases, Madrid, 1839.

Ley Electoral de 1837.

LóPEZ, J. M.ạ: Colección de discursos parlamentarios de Don Joaquín María López, Madrid, 1836.

López Escobar Fernández, F.: Los origenes del Derecho presupuestario español, Inst. de Estudios Administrativos, Madrid, 1971.

"Los principios financieros en las leyes constitucionales españolas (Del Estatuto de Bayona a la Constitución de 1857)", en Cuadernos Bibliográficos de Hacienda Pública, II, n.ํ5, Deusto-Bilbao, 1959. 
MadRazo, Francisco: Las Cortes españolas: resumen histórico de las tres épocas parlamentarias, Imp. de D. A. Babia, Madrid, 1857.

MAgin FerRer y Pons: Las leyes fundamentales de la Monarquía española, Barcelona, 1843.

Manual del Congreso de los Diputados, Imp. Nacional, Madrid, 1864; 345 págs. + VIII.

Marcuello, J. T.: La práctica parlamentaria en el reinado de Isabel II, Madrid, 1986.

Martinez Cuadrado, Miguel: "Trayectoria del sufragio en España", en Historia, abril, 1977.

Martinez SosPedra, Manuel: «Empleados, diputados y ministros", en Actas del III Symposium sobre Historia de la Administración, Inst. de Estudios Administrativos, Madrid, 1974, 605-627.

Medina Muñoz, M. Ángel: "La reforma constitucional de 1845", en Revista de Estudios Políticos, núm. 203, Madrid, sep.-oct. 1977.

Medina Ortega, Manuel: "El derecho de asilo diplomático en España», en Boletín Informativo del Seminario de Derecho Político, núm. 32, Salamanca, 1964, 123-35.

Mora, Miguel: Oradores políticos, Madrid, 1890.

Navarro Amandi, Mario: "Estudios sobre procedimiento electoral», en Revista de Legislación, Madrid, 1885.

NiETo, Alejandro: "Influencias extranjeras en la evolución de la ciencia española del Derecho administrativo", en Anales de la Universidad de la Laguna de la Facultad de Derecho, III, 1965-1966, 43-68.

Olivar Bertrand, Rafael: Oratoria política y oradores del ochocientos, Bahia-Blanca, 1960.

Olózabal Mendoza, Javier: "Significación y posición juridica de los Fueros Vasco-Navarros desde la primera a la última guerra carlista (18331876)", en Revista de la Universidad de Madrid, III, núm. 10, 1954.

PACHECO, Joaquín Fco.: Lecciones de Derecho político constitucional, pronunciadas en el Ateneo de Madrid en 1844, Imp. Ignacio Boix, Madrid, 1844-1845.

PASTOR Diaz, N.: Discurso sobre la reforma de la Constitución de 1837 pronunciado en el Congreso en la sesión de 30 de Octubre de 1844, publ. en Obras Completas, ed. de la B.A.E., Vol. II. 
Pérez Serrano, Nicolás: "Constitucionalismo y codificación", en Revista General de Legislación y Jurisprudencia, XXV, 1953, 92-104.

Posada, A.: Régimen parlamentario de la práctica (s. i.), 1932.

- Evolución legislativa del régimen local (s. i.), 1910.

Proyecto de Constitución. Formado por el Ministerio Istúriz, precedido de un discurso... sobre la monarquía representativa por $D$. N. N., El Mundo, Madrid, 1836.

Rıco Y AMAT, Juan: Historia política y parlamentaria de España, Madrid, 1860-1861, Madrid, 1862.

- Diccionario de los politicos, Madrid, 1855.

- El libro de los diputados y senadores, Madrid, 1862.

Ríos, Juan Miguel de los: Derecho político general español y europeo, 3 vols., Imp. Ignacio Boix, Madrid, 1846.

Sáinz DE VARANDA, Ramón: "Principales manifestaciones históricas del poder constituyente", en Boletín de la Universidad Compostelana, LXVII, Santiago de Compostela, 1959.

Sánchez Agesta, Luis: Historia del constitucionalismo español, Inst. de Estudios Políticos, Madrid, 1964.

- "Los principios del constitucionalismo español, soberanía nacional y constitución interna», en Archivo de Derecho Público, VI-VII, Universidad de Granada, 1953-54, 13-32.

- "Significado y evolución del constitucionalismo español", en Constituciones y leyes fundamentales de España, Granada, 1954.

Sela Quintana, Luis, "El poder real en las constituciones españolas del siglo XIX», en Revista de la Escuela Social de Oviedo, VII, núm. 11, 1954, $31-40$.

Sevilla Andrés, Diego: Constituciones y otras leyes y proyectos políticos de España, Editora Nacional, Madrid, 1969.

- Historia constitucional de España (1800-1936), Escuela Social, Valencia, 1966.

- "La función legislativa en España (1800-1868)", en Revista del Inst. de Ciencias Sociales, núm. 6, Barcelona, 1965.

- Orígenes de la crítica social en España (1800-1856), Facultad de Derecho de Valencia, Valencia, 1975. 
- "El poder constituyente en España de 1800 a 1868", en Revista del Inst. de Ciencias Sociales, núm. 4, Barcelona, 1964.

- "El Senado de 1845", en Homenaje a D. Nicolás Pérez Serrano, II IHE n. 934.100$), 3-28$.

"Significado y evolución del constitucionalismo español", en Constituciones y leyes fundamentales de España, V-XVI, núm. 12.358 (IHE).

Solé TuRA, J., y AJA, E.: Constituciones y períodos constituyentes en España (1808-1936), Siglo XXI, Madrid, 1978.

"Textos constitucionales españoles (1808-1947)", en Archivo de Derecho Público, VI-VII (Universidad de Granada), Granada, 1953-54, 163-387.

Tierno Galván, E.: Leyes politicas españolas fundamentales (1808-1836), Tecnos, Madrid, 1968.

Tomás Villarroya, Joaquín: "El cuerpo electoral en la Ley de 1837", en Revista del Inst. de Ciencias Sociales, núm. 6, Barcelona, 1965, 157-205.

- El sistema político del Estatuto Real, Inst. de Estudios Políticos, Madrid, 1968.

- "Las primeras elecciones directas en España", en Anales de la Universidad de Valencia, XXXVIII, cuaderno II, derecho, 1964-1965, 7-56.

- "La redacción y publicación del Estatuto Real», en Revista de Estudios Políticos, núm. 145, Madrid, 1966, 47-77.

- "La Constitución de 1812 en la época del Estatuto Real», en Revista de Estudios Políticos, núm. 126, Madrid, 1962.

- "Las reformas de la Constitución de 1812 en 1836", en Revista del Inst. de Ciencias Sociales, núm. 4, Barcelona, 1964.

Torres del Moral, A.: Constitucionalismo Histórico español, Madrid, 1986.

ULL PONT, Eugenio: «El sufragio censitario en el Derecho electoral español», en Revista de Estudios Políticos, núm. 194, Madrid.

- "Derecho electoral de España (1810-1967)". Tesis doctoral 1970, en Revista Madrid.

- "Origenes del Derecho electoral español», en Boletín Informativo del Departamento de Derecho Político, UNED, núm. 2, Madrid, 1978.

Valdés Y MENÉndez Valdés, José Luis: "La confusión de estados en historia», en Hidalguía, XV, núm. 82, Madrid, 1967, 398-416. 
Valgonera, Marqués de: "Reflexiones sobre la Ley Electoral de 1837: Vicios e inconvenientes de la elección completa", en Revista de Madrid, t. I, Madrid, 1838, 76-92.

VÁzouez de Prada: «Evolución histórico-constitucional en la regulación de los derechos fundamentales", en Revista de Estudios Políticos, núms. 189-190, Madrid, 1973.

\section{RÉGIMEN POLITICO}

\subsection{Monografias del reinado de Isabel II}

Acedo Castilla, José F.: Donoso Cortés y la Revolución de 1848, Sevilla, 1956.

Alonso Baquer, M.: El modelo español de pronunciamiento, Madrid, 1983.

Aronson, Theo: Venganza real. La Corona de España, 1829-1965. Con un apéndice, 1966-68 (trad. de Enrique de Obregón), Grijalbo, Barcelona, 1968, Col. "Norte".

BahAmonde, A., y ToRo, J.: Burguesía, especulación y cuestión social en el Madrid del siglo XIX, Madrid, 1978.

BaLmes, J.: El General Narváez, en O.C., ed. BAC, Vol. VII.

- Examen de la cuestión del matrimonio de la reina Doña Isabel II, recopilados en Obras Completas, ed. B.A.C., Vol.

- El matrimonio de la Reina con el Conde de Montemolín, Vol. VII.

Barcelona en julio de 1840. Sucesos de este período, con un apéndice de los acontecimientos que siguieron hasta el embarque de S.M. la Reina Gobernadora en Valencia, J. Tauló, Barcelona, 1844.

Borrego, A.: La Revolución de Julio de 1854 apreciada en sus causas y en sus consecuencias, Madrid, 1855.

Burgos, Javier de: Anales del reinado de Isabel II, Mellado, Madrid, 18501851.

Cabeza Sánchez Albornoz, F.: Los sucesos de 1848 en España, Madrid, 1981. 
Cambronero, Carlos: "La Reina Gobernadora. Crónicas políticas de 1833 a 1840", en La España moderna, CCCV, 58-81; CCCVII, 105-117; CCCX, 526; CCCXII, 5-24, 1914.

CAMPS GIRÓ, J.: La guerra dels Matiners i el catalanisme politic (1846-1849), Barcelona, 1978.

De Castro, C.: La Revolución liberal y los municipios españoles, Madrid, 1979.

Donoso CoRTés, J.: Sobre la candidatura del Conde de Trápani, recogida en Obras Completas, ed. de la Biblioteca de Autores Cristianos, Vol. II.

Fermín Caballero: Casamiento de la Reina Cristina con Don Fernando Munoz, Madrid, 1840.

Fernández de Córdoba, F.: Mis memorias intimas, ed. de la B.A.E., Vol. II.

Figueroa y Torres, Álvaro de C. R.: Un drama político: Isabel y Olózaga, 2.a ed., 169 págs.

FonTANA, J.: La Revolución Liberal (politica y Hacienda, 1833-1845), Madrid, 1977.

Garcia Monerris, C.: Las barricadas de julio de 1854. Análisis sociológico, Madrid, 1976.

Garaido, F.: Historia del reinado del último Borbón de España, Barcelona, 1869.

Gil Morales, A. (ed.): La Revolución burguesa en España, Madrid, 1985.

Gı SÁnCHEZ, Fernando: Palacio municipal y palacio real. La visita de Isabel II a Alicante, Alicante, 1965.

Güell y Rente, José: Paralelo entre las Reinas Católicas Doña Isabel l y Doña Isabel II, 1858.

Guirarte, Martín: D. Juan Prim. México y Napoleón, Ambos Mundos, México, 1962.

Janke, P.: Mendizábal y la instauración de la Monarquía Constitucional en España 1790-1853, Madrid, 1974.

Jiménez-Land, Antonio: Esos días..., Aguilar, Madrid, 1965.

JOVER, J. M.: "Situación social y poder político en la España de Isabel Il", publ. en la obra miscelánea Historia Social de España S. XIX, ed. Guadiana, Madrid, 1972. 
- El siglo XIX en España: doce estudios, Barcelona 1974.

Kiernan, V. G.: La Revolución de 1854 en España, Madrid, 1970.

KunTz, Harold: The Empress Eugenie, 1826-1920, Londres, 1964.

Larrayoz Zarranz, Pbro., Javier: La segunda guerra carlista en Navarra 1848-1849, Príncipe de Viana, Pamplona, XVII, n. 63, 1956.

LIDA, C .E., y ZAVALA, I. M.: La revolución de 1868, Madrid, 1970.

LuARD, René: Isabel /l de España (la Reina Generosa), Gráf. Ampurias, AHR, Barcelona, 1958.

Luz, Pierre de: Isabel II, Barcelona, 1940.

- Isabel II, reina de España (1830-1904), Juventud, Barcelona, 1962.

Llabres Bernal, Juan: Reina D. ${ }^{a}$ Isabel II. El último navío español, 18521889, ed. Alfa, Palma de Mallorca, 1963.

LlorCA, Carmen: Isabel Il y su tiempo, Ed. Marfil S. A., Alcoy, 1956.

- "Los sucesos de la Granja y el Conde de Solaro", en Revista de la Universidad de Madrid, III, núm. 11, Madrid, 1954, 347-356.

MARíAS, Julián: Una tradición olvidada, Ínsula, Madrid, XIV, n.ำ 151, 1959.

MARLIANI, Manuel: La regencia de don Baldomero Espartero, conde de Luchana, duque de la Victoria y de Morella y sucesos que la prepararon, M. Galinao, Madrid, 1870.

Mina, M. C.: Fueros y Revolución Liberal en Navarra, Madrid, 1984.

Miquel I Verges, J. M.: El General Prim en España y en México, México, 1949.

MiRaflores, Marqués de: Memorias del reinado de lsabel ll. Edición y estudio de Manuel Fernández, Ed. Atlas (Imp. Estades), Madrid, 1964.

- Memorias para escribir la historia contemporánea de los siete primeros años del reinado de Isabel II, Madrid, 1843. Continuación de las memorias públicas para escribir la historia del reinado de Isabel II, Madrid, 1873.

MuÑiz, R.: Apuntes históricos sobre la Revolución de 1868, Madrid, 1886.

Navarro Rodrigo, C.: O'Donnell y su tiempo, Madrid, 1869. 
Nieva, J. M. a de: Decretos de la Reina Nuestra Senora, Doña Isabel Il, dados en su Real Nombre por su Augusta Madre la Reina Gobernanta, tomos XIX, XX, XXI, Imp. Real, Madrid, 1835, 36.

Oliva Marra-López, Andrés: "Andrés Borrego, político malagueño del siglo XIX", Revista de Estudios Políticos, LXI, n.9 95, Madrid, 1957.

Oliver Bertrand, Rafael: Siglo de pasión política. Así cayó Isabel Il, ed. Destino, Barcelona, 1955.

- El caballero Prim, Barcelona, 1952.

Ordenanza general para el Gobierno y Administración de la Real Casa y Patrimonio, espedida en 29 de mayo de 1840, E. Aguado, Impresor de Cámara de S.M., Madrid, 1840.

PABón, Jesús: Narváez y su época, Madrid, 1983.

- "La leyenda y la historia del General Narváez". Conferencia inaugural del XXXI Congreso Luso-Español para el Progreso de las Ciencias, Cádiz, abril 1974.

Pando Fernández de Pinedo, Manuel: Memoria para escribir la historia... de los siete primeros años del reinado de Isabel II por el marqués de Miraflores, Viuda de Calero, Madrid, 1843-44.

Pardo Canalis, Enrique: "lconografía de "Los sucesos de La Granja" ", en Goya, n. 9 92, Madrid, 1969, 83-88.

Paredes Alonso, F. J.: Pascual Madoz, 1805-1870: Libertad y progreso en la monarquía isabelina, Pamplona, 1982.

Polnay, Peter de: A queen of Spain. Isabel II, Hollis and Carter, Londres, 1962.

Prieto-Castro, L.: "Sobre el reinado de Isabel ll», en Ambos Mundos, n.ㅇ 6, México, 1963.

PugA, M. - Teresa: El matrimonio de Isabel II. Universidad de Navarra, Pamplona, 1964.

Relación histórica del origen, progreso y definitivo resultado de las cuestiones de la tutela de S.M. Doña Isabel II y de la... Infanta Doña Luisa Fernanda, E. B. Delaudhy (s.a.), Paris.

Reparaz, Gonzalo: Política de España en África, Barcelona, 1907.

Revesz, Andrés: Un dictador liberal: Narváez, Aguilar, Madrid, 1953. 
RodRiguez del Coro, F.: Revolución burguesa e ideologia dominante en el País Vasco (1866-1872), Vitoria, 1985.

Rubio MañE, J. Ignacio: «El General Prim y el Ministro de Hacienda don José González Echeverría. Las actuaciones del General Prim en México, 1862", Boletín del Archivo General de la Nación, V, n.ำ1, México, 1964.

Saltillo, Marqués de: «Don Manuel Barrio Ayuso y el motín de La Granja (1836)", en Celtiberia, IV, n.o 7, 1854, 7-19.

San Miguel, Evaristo: Breves observaciones sobre los sucesos de agosto de 1836 y sus resultados, M. de Burgos, Madrid, 1838.

- De los facciosos. M. de Burgos, Madrid, 1837.

- La cuestión romana, Imp. Calle de la Ballesta, Madrid, 1849.

Santillán, Ramón de: Memorias (1815-1856). Edición y notas de Ana M. ${ }^{\text {a }}$ Berazaluce. Introducción de Federico Suárez. Estudio General de Navarra (Colec. Histórica, n. 3), Pamplona, 1960.

SeVILla Andrés, D.: La revolución de 1854. Anales de la Universidad de Valencia, Vol. XXXIII, cuaderno III (de carácter monográfico), 19591960.

- Historia política de España (1800-1873), 2.. ed., Madrid, 1974.

Sото, M.: La España Isabelina, Madrid, 1979.

SuÁrez, Federico: Los sucesos de La Granja, CSIC, Escuela de Historia Moderna, Sección de Santiago, Madrid, 1953.

Torres y Valcázar, Pilar: "Relación de expedientes de títulos nobiliarios que se conservan en el Archivo del Ministerio de Justicia", en Hidalguia, VI, n.. 28, 433-464; n. 29, 633-664, Madrid, 1958.

TREND, Julio: Fermín Arteta, ministro de Isabel /l (la anticipación de un tecnócrata), Guadarrama, Madrid, 1971.

Trias, J., y Elonza, A.: Federalismo y Reforma Social en España (18401870), Madrid, 1975.

Trigo Real, Joaquin: Monedas de Isabel II (años de 1833 al 1868). Editor Joaquín Trigo Real, Barcelona, 1974.

TuÑón de LARA, Manuel: "¿Qué fue de la Década Moderada?", en Estudios sobre el siglo XIX en España, Madrid, 1972. 
Villalpando, Manuela: "Relatos de los sucesos de 1836 en Madrid", en Estudios Segovianos, III, n.ำ 13, 1952, 587-591.

ZorriLla, José: Recuerdos del tiempo viejo. Prólogo de José Luis Martín, Madrid, 1961.

\subsection{Gobierno}

África en el pensamiento de Donoso Cortés. C.S.I.C. Instituto de Estudios Africanos, Madrid, 1955.

Álvarez Mendizábal, Juan: Exposición dirigida a las Cortes de la nación española resumiendo la cuenta que tiene dada del uso que hizo del voto de confianza contenido en la Ley de 16 de enero de 1836, Madrid, 1837.

- Exposición y documentos dirigidos al Gobierno de S. M. Observaciones a la anterior "Exposición", por don Ramón Santillán, Madrid, 1836-37.

- Memoria presentada a las Cortes de la Nación... sobre el Presupuesto General de Cortes y recursos para llenar el depósito de 1837, Madrid, 1837.

Andrés Vázouez, José: "Los leones del pórtico de las Cortes españolas", África, XV, Madrid, 1958.

Arechaga y LANDA, Juan José: Memoria sobre los presupuestos... del Estado..., Imp. del Colegio de Sordo-Mudos y Ciegos, Madrid, 1845.

BelzA, Julio: "¡Aquella guerra de hace cien años!», Pensamiento y Acción, $X I$, n. 112, Barcelona, 1960.

Bravo Murillo, J.: Política y administración en la España Isabelina. Antología preparada por J. L. Comellas, Madrid, 1971.

Cárdenas Rodriguez de Moya, J. M.: "Sistemas de representatividad de las corporaciones municipales en el constitucionalismo español", en Actas del III Symposium de Historia de la Administración, Inst. de Estudios Administrativos, Madrid, 1974, 689-716.

Carrasco Canals, C.: La burocracia en la España del siglo XIX, Madrid, 1975.

CASTEL, Jorge: Actividades de España en Marruecos desde principios del siglo XIX, Madrid, 1954. 
CAstillo y Ayensa, José del: Historia crítica de las negociaciones con Roma desde la Muerte de Fernando VII, Tejado, Madrid, 1859.

Clavero Arévalo, Manuel Francisco: "L'uniformité administrative en Espagne", en Revue Internationale del sciences administratives, XXII, núm. 2, Bruselas, 1956, 47-65.

Correa Viera, Agustín: Un aspecto poco conocido de Bravo Murillo. El R.D. que creó los puertos francos de Canarias, Badajoz, 1964.

Delgado, Jaime: España y México en el siglo XIX. Tomo II: 1831-1845. C.S.I.C. Instituto Gonzalo Fdez. de Oviedo, Madrid, 1953.

EIRAs Roel, Antonio: "La unificación italiana y la diplomacia europea", $R e-$ vista de Estudios Políticos, n. 133, Madrid, 1964.

Elorza, Antonio: "El proyecto de ley Alonso Martínez sobre el trabajo en la industria", en Revista del Trabajo, 27-28, Madrid, 1969, pp. 251484.

Espronceda, José de: El Ministerio de Mendizábal (s. i.), Madrid, 1856.

Estadistica del personal y vicisitudes de las Cortes y de los Ministerios de España, desde el 29 de septiembre de 1833 hasta el 24 de diciembre de 1879, Imp. de la Viuda e Hijos de J. A. Garcia, Madrid, 1907.

ESTAPÉ, F.: La Reforma Tributaria de 1845, Barcelona, 1971.

Extracto de la causa seguida a sor Patrocinio, por el Juzgado de BarquiIlo, precedida de la relación de todo lo acaecido en la subida al poder y caida del Ministerio Clonard Manresa Balboa, B. González, Madrid, 1849.

F. CAstañón, César G.: «Tensión diplomática hispano-inglesa en Portugal (1846-1847)», Cuadernos de Historia Diplomática, II, Zaragoza, 1955.

fERnÁndez García, Antonio: El abastecimiento de Madrid en el reinado de Isabel II, Inst. de Estudios Madrileños, CSIC, Madrid, 1971.

Ferrandis Torres, Manuel: "Consecuencias políticas y sociales de la guerra de 1860". Archivos del Instituto de Estudios Africanos, XIV, n. ${ }^{54}$, Madrid, 1960.

Finat, Hipólito: España y Marruecos. Perspectiva social e internacional de España desde 1815 hasta 1931, Inst. General Franco, Tetuán, 1954.

Gallego Anibarte, Alfredo: “Notas histórico-juridicas sobre el régimen local español (intento de revisión)", en Actas del // Symposium de His- 
toria de la Administración, Inst. de Estudios Administrativos. Estudios de Historia de la Administración, Madrid, 1971, 529-541.

García Tejero, Alfonso: Historia político-administrativa de Mendizábal, J. A. Ortigosa, Madrid, 1858.

- Historia político-administrativa de Mendizábal. Dedicado al pueblo liberal español, Tip. J. A. Ortigosa, Madrid, 1950.

Ghisalberti, Alberto M.: "L'archivio dell'Ambasciata di Spagna presso la Santa Sede". Rasegna storica del Risorgimento, XL, 1953.

Gorricho Moreno, Julio: “Los sucesos de La Granja y el cuerpo diplomáticon, en Anthologica Annua, núm. 4, Roma, 1966, 243-437 (separata).

Gobiernos de los políticos y de las Intendencias civiles, por D.I.C.P. Serie "Eco de Numancia", Soria, 1842.

GonzÁlez-Rothovos y GIL, Mariano: "Las relaciones luso-españolas en el siglo XIX en materia de migraciones", en Revista Internacional de Sociología, XX, núm. 80, Madrid, 1962.

Guirarte, Martín: «D. Juan Prim, México y Napoleón». Ambos Mundos, I, n.․ 4, México, 1962.

GustaVino Gallent, Guillermo: De ambos lados del Estrecho (Estudios breves hispano-africanos). Instituto General Franco, Tetuán, 1955.

Heredia y Begines de los Rios, Narciso de, conde de Otalia: Cartas del... al marqués de Espeja, ministro en Francia (1838). (Publicaciones por el marqués del Saltillo.) Tirada aparte del Boletín de la Real Academia de la Historia, 1943, 49 págs.

Historia verídica de los diez días del Ministerio López y contestación al folleto titulado "Historia de las sesiones del Congreso en los dias 19 y 20 del mes de mayo por...", Imp. D. I. Boix, Madrid, 1843, 43 págs.

JOVER, José M.a: "Caracteres de la política exterior de España en el siglo XIX", en Homenaje a Johannes Vincke, vol. II, CSIC y la Goerresgesellschaft zur pflege des Wissenschaft, Madrid, 1962-1963, 751-794.

La Puente, Esteban de: «1861-1865 Anexión y abandono de Sto. Domingo. Problemas críticos", Revista de Indias, XXII, n. 88-90, Madrid, 1962.

Las Juntas Generales del señorio de Vizcaya y la Guerra de África 18591860). Homenaje que la Excma. Diputación de Vizcaya dedica a los Tercios Vascongados de la Guerra de África en su centenario. Imprenta Provincial de Vizcaya, Bilbao, 1960. 
Los ministros en España desde 1800 a 1869. Historia contemporánea por uno que, siendo español, no cobra del presupuesto, R. Lavajos, Madrid, 1869-1870.

MARTí, CASIMIR: "La correspondencia oficial del cónsul francés a Barcelona 1854-1856", en Serra d'Or, II, n.o 11, Barcelona, 1960.

Martín Niño, Jesús: La Hacienda española y la Revolución de 1868. Estudios de Hacienda Pública. Instituto de Estudios Fiscales, Madrid, 1972.

Martin Retortillo y Baquer, S.: "Alejandro Oliván: Notas a su vida y a su pensamiento administrativo", en Argensola, VII, núm. 2 ("Homenaje a Ricardo del Arco", II), Huesca, 1956, 127-152.

Martínez Cachero, L. Alfonso: "Alejando Mon y la reforma tributaria de 1845". Boletín del Instituto de Estudios Asturianos, XIX, n. 56, Oviedo, 1965.

Medina Ortega, Manuel: "El derecho de asilo diplomático en España». Boletín informativo del Seminario de Derecho Político, n. 32 , Salamanca, 1964.

Medrano Esouerra, Carmelo: "Aspecto militar de la Guerra de África 1859$60 \%$. Archivos del Instituto de Estudios Africanos, XIV, n. 54 , Madrid, 1960.

MESA, Roberto: El colonialismo en la crisis del XIX español, Ediciones Ciencia Nueva, Madrid, 1967.

Morales Oliver, Luis: "La Guerra de África en Pedro Antonio de Alarcón". Archivos del Instituto de Estudios Africanos, XIV, n. 54, Madrid, 1960.

Nieto, A.: La retribución de los funcionarios en España. Historia y actualidad, Madrid, 1967.

O'COCHLAIN, Rupert S.: Leopold O'Donnell and the spanish maroccan Campaign, 1859-1960. The Irish Sword, VII, Dublín, 1965-66.

OlIVÁN, Alejandro: De la administración pública con relación a España. Prólogo de E. Garcia de Enterria. Instituto de Estudios Politicos, Madrid, 1954.

Olivar-Bertrán, R.: "Notas sobre la visión norteamericana de España de 1860 a $1870 \%$. Revista de Occidente, 2. época, n.ํํㄹ 22, 1965.

Olivart, Marqués de: Colección de los tratados... internacionales... desde Isabel II. Notas histórico-críticas, El Progreso Editorial, Madrid, 1912. 
Pagnoul, Anne-Marie: Ministère de I'Interieur. Affaires electorales, 18301919. Inventaire, Archive Générale du Royaume, Bruselas, 1972.

PéRez de LA CANAL, M. Ángel: Notas sobre el régimen legal de los gobernadores civiles (1812-1958). Publicaciones de la Secretaría General Técnica del Ministerio de la Gobernación (Col. Estudios, 6), Madrid, 1964.

Reseña documentada de los principales negocios que se han ventilado por el Ministerio del Estado desde el mes de octubre de 1840 hasta la reunión de las Cortes de 1841. Alegría y Charlain, Madrid, 1841.

Rubio Mañe, Jorge Ignacio: “El General Prim y el ministro de Hacienda, don José González Echevarría. Las actuaciones del General Prim en México, 1862". Boletín del Archivo General de la Nación, 2. serie, IV, n. 4, México, 1963.

SÁNCHEZ BELLA, Ismael: "La reforma de la Administración Central en 1834", en Actas del III Symposium Historia de la Administración, Instituto de Estudios Administrativos, Madrid, 1974, 655-688.

Sánchez Diana, José M. a: "Anexión de la isla de Sto. Domingo a España bajo el reinado de Isabel II". Anuario de Estudios Americanos, XI, SeviIla, 1954.

SeVILla ANDRÉs, Diego: "Antecedentes políticos de la Guerra de 18591860 ". Archivo del Instituto de Estudios Africanos, XIV, n.54, Madrid, 1960.

- "Origenes del Gobierno de Gabinete en Orgaz", en Revista General de Derecho, 1947.

SILIó, Javier de: «El Archivo Histórico del Ministerio de Asuntos Exteriores de Italia y la historia del siglo XIX español. Documentos referentes a España en la "Segreteria di Stato degli Affari Esteri" de Carlos Manuel de Cerdeña (1831-1849)", en Cuadernos de Trabajo de la Escuela Española de Historia y Arqueología en Roma, VIII, 1956, 159 198.

Tomás VIllarroya, Joaquín: "El Decreto del 21 de septiembre de 1835 sobre organización de las Diputaciones Provinciales", en La Provincia (IHE, núm. 61671), I, 53-61.

URmeneta Sesma, Lázaro: El valle de Erro y el Tratado de Límites entre España y Francia de 2 de Diciembre de 1856, Pamplona, 1956.

VAN AKen, Mark J.: Pan-Hispanism. Its origin and development to 1866 , Berkeley - Los Ángeles, 1959. 
VICENS VIVES, J.: "Governo ed oppinione pubblica in Spagna durante la crisi della Guerra di Crimea", en Atti del XXXV Congresso di storia del Risorgimento Italiano, Roma, 1959.

- "La diplomazia spagnola di fronte alla crisi italiana del 1859", en Atti del XXXVIII Congresso di storia del Risorgimento Italiano, Roma, 1960.

Wagner de ReYNA, Alberto: Las relaciones diplomáticas entre el Perú y Chile durante el conflicto con España (1864-1867), Lima, 1963.

\subsection{Cortes}

Álvarez Mendizábal, Juan: Observaciones del Congreso, Madrid, 1838.

BorregO, Andrés: El libro de las elecciones. Reseña histórica de las verificaciones durante los tres períodos del régimen constitucional: 181014, 1820-23, 1834-73, Imp. Española, Madrid, 1874.

- Estudios parlamentarios efectuados de orden de las Cortes con aplicación a la reforma del reglamento de Gobierno interior del Congreso, Sociedad Tipográfica, Madrid, 1875.

BöHL DE FABER, Cecilia (Fernán Caballero): Resultados de las últimas elecciones para diputados y senadores, Imp. de Eusebio Aguado, Madrid, 1837.

- Fisonomía natural y política de las jornadas en las Cortes de 1834, 35 y 36, Imprenta de Ignacio Boix, Madrid, 1836.

Bertelsen Repetto, Raúl: "El Senado en España», en Actas del III Symposium Historia de la Administración, Instituto de Estudios Administrativos, Madrid, 1974, 409-431.

Caballero: Reseña de las últimas elecciones para diputados y senadores, Madrid, 1837.

Cadenas y VICEnT, Vicente de: "Índice de los senadores vitalicios», en Hidalguía, XI, núm. 59, 465-480; núm. 60, 577-592; núm. 61, 735-752; Madrid, 1963.

Cambronero, Carlos: "Las Cortes de Isabel II. Crónicas parlamentarias", en La España Moderna (1910), CCLIX, 90-110; CCLX, 69-92; CCLXI, 47-76; CCLXII, 61-64; CCLXIII, 67-96; CCLIV, 78-102; (1911), CCLXV, $36-65$. 
Campuzano, Joaquín Francisco: La verdad dirigida a las Cortes, M. de Burgos, Madrid. 1838.

CongRESO de los DiPUTAdos: Organización y funcionamiento de las Cortes según la Constitución española y reglamento de dicho cuerpo colegislador. Exposición sintética por Adolfo Pons y Umbert. Imp. Hijos de M. G. Hernández, Madrid, s. f.

- Reglamento del Congreso de los Diputados, Imp. del Colegio de Sordomudos, Madrid, 1938.

Diario de las sesiones de Cortes. Estamento de llustres Próceres (Senado) (s. i.), Madrid, 1834-1922.

Diario de Sesiones. Cortes del Reino desde 1808 (Congreso) (s. i.), Madrid, 1880,568 vols.

Fernández Almagro, Melchor: "Las Cortes del siglo XIX y la práctica electoral», en Revista de Estudios Políticos, vol. 5, Madid, 1943.

Guimera Peraza, Marcos: Los diputados doceañistas canarios, Aula de Cultura, Tenerife, 1967.

Los diputados americanos en las Cortes españolas. Los diputados de Puerto Rico, 1872-1873, Madrid, 1880.

Martinez Ruiz, Enrique: "La actuación del hebraísta García Blanco en las Cortes Constituyentes de 1837", en Miscelánea de Estudios Árabes y Hebraicos, XVIIIXIX, núm. 2, Granada, 1969-1970, 89-127.

Martínez SOSPEdRa, Manuel: Incompatibilidades parlamentarias en España (1810-1936), Facultad de Derecho de la Universidad de Valencia, 1974.

Pando Fernández de Pinedo, Manuel (marqués de Miraflores): Discurso histórico sobre las Cortes de España en los tres últimos siglos, leído en la Real Academia de la Historia el 5 de julio de 1850, Imp. Real Academia de la Historia, Madrid, 1850.

PAstor Díaz: A las Cortes y a los diputados. Palabras de un diputado conservador sobre las principales cuestiones de nuestra situación política, Imp. de Corrales y Cía., Madrid, 1846.

Pons y UMBERT, Adolfo: Organización y funcionamiento de las Cortes, Madrid, 1906.

Reglamento de procuradores a Cortes. Años 1834-1869. Imp. de S. A. García, Madrid, 1869-76, 3 vols. 
Reglamento para el gobierno interior del Senado, Madrid, 1838.

Reglamento para el gobierno interior del Senado aprobado el 26 de enero de 1842, Imp. Nacional, Madrid, 1842.

Rico y Amat, José: El libro de los diputados y senadores. Juicios... de los oradores más notables desde las Cortes de Cádiz..., con la inscripción integra del mejor discurso que cada uno de ellos ha pronunciado (2. ${ }^{\text {a }}$ parte de la Historia política y parlamentaria de España), Vicente y Lavajos, Madrid, 1862-66.

- Historia política y parlamentaria de España, Imp. de las Escuelas Pias, Madrid, 1860-61.

Saco, José Antonio: Examen... del informe de la Comisión... sobre la exclusión de los actuales y futuros diputados de Ultramar y sobre la necesidad de regir aquellos países por leyes especiales, Imp. Jordán, Madrid, 1837.

Sevilla Andrés, Diego: "El Senado de 1845", en la obra Homenaje a don Nicolás Pérez Serrano, vol. II, Madrid, 1959.

- "La Presidencia del Congreso de los Diputados (1810-1936)", en Revista del Instituto de Ciencias Sociales, núm. 14, Barcelona, 1969, 21-56.

TAPIA OzCARIZ, Enrique de: Luz y taquigrafos (Un siglo de Parlamento en España), Aguilar (Col. Panorama de un siglo), Madrid, 1961.

TOMÁs VilLARROYa, Joaquín: "Los orígenes del control parlamentario en España», en Revista de Estudios Políticos, núm. 132, Madrid, 1963.

VIDAL y SAURA, Ginés: La política exterior de España durante la menor edad de Isabel II. Prólogo del marqués de Villa-Urrutia (Wenceslao R. VillaUrrutia), Ed. Reus, Madrid, 1929.

Villanueya, J. L.: Mi viaje a las Cortes, Imp. Nacional, Madrid, 1860.

\section{FUERZAS SOCIALES Y POLITICAS}

\subsection{Liberales}

Abellán, J. L.: Fernando de Castro. Memoria testamentaria. El problema del catolicismo liberal, Castalia, Madrid, 1975.

ARTola, Miguel: "Caracteres sociales del liberalismo", en Revista de Trabajo, núm. 7, Madrid, 1964. 
Azcárate, Gumersindo de: Olózaga. Origen, ideas y vicisitudes del partido progresista. El Parlamento desde 1840 a 1866.

Avilés Fernández, M.; Madrazo, Santos; Mitre Fernández, E.; Palacios Martín, B.; REDondo CASTRO, Isabel: Liberalismo y absolutismo, EDAF (Nueva Historia de España, 15), Madrid, 1974.

BerRUEZO, José: "El antiforalismo liberal en la primera guerra carlista», en Boletín de la Real Sociedad Vascongada de los Amigos del País, XXIII, núm. 1, San Sebastián, 1967, 27-36.

Cánovas Sánchez, F.: El partido moderado, Madrid, 1982.

Comellas, José Luis: La teoría del régimen liberal español, Instituto de Estudios Políticos (Empresas Políticas, 9), Madrid, 1962.

- Los moderados en el poder, 1844-54, Escuela de Historia Moderna, CSIC, Madrid, 1970.

Derozier, Albert: "Manuel José Quintana et la naissance du liberalisme en Espagne", en Les Belles Lettres (Annales littéraires de I'Université de Besançon, vol. 95), París, 1968.

Diez del Corral, Luis: El liberalismo doctrinario, 2." ed., Instituto de Estudios Políticos, Madrid, 1956.

DuRÁn de la RúA, N.: La Unión Liberal y la modernización de la España Isabelina. Una convivencia frustrada, 1854-1868, Madrid, 1979.

Eggers, Eduardo R.... y Enrique Feune de Colombí: Francisco de Zea Bermúdez y su época, 1779-1850, CSIC, Imp. Pueyo, Madrid, 1958.

EIras Roel, Antonio: El Partido Demócrata Español, Ed. Rialp, Madrid, 1961.

- "Sociedades secretas republicanas en el reinado de Isabel II", en Hispania, XXII, núm. 86, Madrid, 1962.

ElorzA, Antonio: «El liberalismo económico de Vicente Alcalá Galiano», en Moneda y Crédito, núm. 106, Madrid, 1960, 65-87.

Escudero, A.: Ensayo sobre las opiniones políticas en España (s. i.), París, 1837.

Galindo Herrero, Santiago: "Donoso Cortés en la última etapa de su vida", en Arbor, XXV, 1953, p. s.

Garcia Nieto, María del Carmen; Donezar, Javier M., y López Puerta, Luis: Moderados y progresistas (1833-1868), Guadiana de Publicaciones, Madrid, 1971. 
Grases, Pedro: "Algo más sobre "liberal" ", en Nueva Revista de Filología Hispánica, XV, núms. 3-4, México-Austin, 1961, 539-541.

JANKE, Peter: Mendizábal y la instauración de la monarquía constitucional en España (1790-1853), Siglo XXI Editores, S. A., Madrid, 1974.

JURETSCHKe, Hans: "Vida, obra y pensamiento de Alberto Lista". Rc. V. Palacio, Cuadernos de Historia de España, XIX, 1953, 185-188; Rec. Juan Mercader, Hispania, XIV, núm. 54, 1954, 151-154.

LLORENS CASTILLO, Vicente: Liberales y románticos. Una emigración española en Inglaterra (1823-1834), El Colegio de México (Publicaciones de la Nueva Revista de Filologia Hispánica, III), México, 1954. Última edición, Ed. Castalia, Madrid 1979.

Maestre Rosa, Julio: "Javier de Burgos, liberal doctrinario", en Revista de Estudios Políticos, núm. 181, Madrid, 1972, 133-157.

MarichaL, C.: La Revolución Liberal y los primeros partidos políticos en España, 1834-1844, Madrid, 1980.

NARVÁEZ, Francisco: Contestación... a los discursos que en la sesión (del Senadol de 3 de agosto pronunciaron en contra suya los señores Seoane y Heros, E. B. Delanchy, París, 1841.

NARVÁEZ, Ramón María: D. Ramón María Narváez, ex-comandante general de la división de vanguardia del ejército de operaciones, al Congreso Nacional y al público. Arganda, 26-l-1837 (s. i.; s. a.), 23 págs. +10 documentos.

- Manifiesto a las Cortes y a la nación, Madrid, 1837.

Nido y Segalerva, Juan del: Historia política parlamentaria de s. a. don Baldomero Fernández Espartero, Imp. de Ramón Velasco, Madrid, 1916.

OpIsso, Alfredo: Semblanzas políticas del siglo XIX. Espartero, Narváez, O'Donnell, Olózaga, Donoso Cortés, Pastor Díaz, Bravo Murillo, el Bienio, Dulce, Ríos Rosas, Posada Herrera, Rivero, Aparisi y Guijarro Nocedal. El ministerio Miraflores, Calvo Asensio, G. Brabo, Prim, Figueras, Manterola, Varela, Campoamor, Castelar. Hnos. Juan Gil (Tip. de los editores), Barcelona, 1908.

PAstor Díaz: Don Francisco Javier de Burgos, Madrid, 1842.

Pérez Embid, Florentino: "Los católicos y los partidos políticos españoles a mediados del siglo XIX". Nuestro Tiempo, V, n. ${ }^{9}$ 46, Pamplona, 1958. 
Roıg OBIOL, Juan: "Actuación política del progresismo catalán en la crisis del verano de 1835", en Homenaje a V. Vives, II, Universidad de Barcelona, Facultad de Filosofía y Letras, 1967, 546-561.

Ruiz Lagos, Manuel: Liberales en Ávila. La crisis del Antiguo Régimen (1790-1840). Cuesta, Tapia y Larra. Diputación Provincial de Ávila, Ins. "Gran Duque de Alba" (Serie Ensayos, núm. 1), Imp. del "Diario de Ávila", 1967.

San Miguel, E.: Vida de don Agustín Argüelles, Madrid, 1851-52.

SÁnChez Agesta, L.: "El origen de los partidos políticos en la España del siglo XIX", en Historia social de España, Guadiana, Madrid, 1972, 173-185.

- La revolución liberal. Historia del constitucionalismo español, Instituto de Estudios Políticos, Talleres Prensa Española, Madrid, 1955.

- "Sentido sociológico y político del siglo XIX", en Revista de Estudios Políticos, LI, núm. 75, 1954, 23-24.

SeVILla ANDRÉs, Diego: "Los partidos políticos españoles hasta 1868 (Ensayo)", en Revista General de Derecho, XIV, núms. 166-167, Valencia, $1959,682-701$.

Sevilla Merino, Amparo: Joaquín María López, Diputación Provincial de Alicante, Inst. de Estudios Alicantinos, XV, Alicante, 1959 (1960).

Simón PALmer, María del Carmen: «El espionaje liberal en la última etapa de la primera guerra carlista: nuevas cartas de Avinareta y de F. de Gamboa", en Estudios sobre la España liberal, CSIC, Madrid, 1973, 289-380.

SuÁrez Verdaguer: "Planteamiento ideológico del siglo $X I X$ español», en Arbor, X, 1948, 57.

TomÁs VILlarRoya, Joaquín: "Alcalá Galiano entre dos destierros", en Revista del Instituto de Ciencias Sociales, núm. 8, Barcelona, 1966, 155-200.

Zavala, Iris M.: "Las sociedades secretas: prehistoria de los partidos politicos españoles", en Bulletin Hispanique, LXXII, núms. 1-2, Bordeaux, 1970, 113-147.

\subsection{Carlismo}

Antología de los documentos reales de la dinastía carlista preparada por Melchor Ferrer, Madrid, 1951. 
Arfane, E. de: Páginas de la Historia del partido Carlista. Carlos VII y D. Ramón Cabrera, París, 1875.

Aronson, Theo: Royal Vendetta. The Crowns of Spain, 1829-1965, Oldbourne, Londres, 1966.

AvinARETA, Eugenio: Memoria dirigida al Gobierno español sobre los planes de operaciones puestos en ejecución para aniquilar la rebelión en las provincias del Norte de España, Tolosa, 1841; 2. ed., Madrid, 1944.

AzcÁrate, Pablo de: "Pronunciamiento del teniente don Cayetano Cardero (18 de enero de 1935)", en Boletín de la Real Academia de la Historia, CLIX, núm. 1, Madrid, 1966, 117-133.

Azcona, José María: Zumalacárregui. Estudio crítico de las fuentes históricas de su tiempo. Prólogo del conde de Rodezno, Madrid, 1946.

Baroja, Pío: Avinareta o la vida de un conspirador, Ed. Planeta, Barcelona, 1970.

Berruezo, José: "Cómo comenzó la guerra carlista en Guipúzcoa", en Boletín de la Real Sociedad Vascongada de Amigos del País, XIII, núm. 2, San Sebastián, 1957, 101-113.

Blade I Desumvila, A.: Els setges de Gandera i del Castell de Mora d'Ebre, 1836-1838. Rafael Dalmau editor (Episodis de la Historia, 143), Barcelona, 1970.

Borbón, Carlos de: Memorias y diario de Carlos VII. Prólogo, notas, biografías y apéndice de Bruno Ramos Martínez. Imp. Europa, Madrid, 1957.

Bullock, H.: "The British Auxiliary Legion in Spain (1835-1840)", en The Journal of the Royal United Service Institution, XCIX, 1954, 574-576.

Burgo, Jaime del: De la España romántica. Ecos de la guerra de Carlos V, Ediciones Siempre, Pamplona, 1952, 76 págs.

- Fuentes de la historia de España. Bibliografía de las guerras carlistas $y$ de las luchas políticas del siglo XIX. Antecedentes desde 1814 y apéndice hasta 1936. Tomo II: F-M. Prólogo de don Federico Suárez Verdaguer. Tomo III: N-Z. Adiciones y correcciones: A-Z. CSIC, Diputación Foral de Navarra, Inst. Príncipe de Viana, Pamplona, 1954-1955.

CAnga Argùelles, José: Documentos pertenecientes a las observaciones sobre la historia de la guerra de España, Imp. Calero, Madrid, 1835, 3 vols. 
CARR, A. Raymond M.: "Spain. Rule by generals", en Soldiers and governments. Nine studies in civil-military relations. Edited by Michael Howard. Eyre and Spotiswoode, London, 1957, 135-148.

Castells, Carmen: "Dios, Patria, Rey: el ideario carlista frente al liberalismo", en Boletín de la Real Sociedad Vascongada de Amigos del País, XXIII, núms. 3-4, San Sebastián, 1958, 343-367.

CASTILLO Y MAYONE, Joaquín del: Los exterminadores o planes combinados por los enemigos de la libertad para dominar la especie humana bajo el pretexto de defensores del Altar y el Trono, Barcelona, 1835.

Córdoba, Buenaventura de: Vida militar y política de Cabrera, Madrid, 1814,4 vols.

Cory, Hane Hamilton: "Las guerras carlistas en la literatura contemporánea", en Revista de la Universidad de Madrid, III, núm. 12, 1954, 532533.

Снасно, J. Agustín: Voyage par Navarre pendant l'insurrection des basques (1830-1835), Bayona, 1865, 2. serie.

ChAO, Eduardo: La guerra de Cataluña. Historia contemporánea, Ed. Baltasar González, Madrid, 1847, XVI + 119 págs.

Descola, Jean: "Don Carlos, Roi d'Espagne», en Revue des Deux Mondes, núm. 3, 1970, 529-543.

- Diario de guerra del teniente general don José Ignacio de Uranga (1834-38). Prólogo de José Berruezo. Publ. de la Excma. Diputación de Guipúzcoa, San Sebastián, 1959.

Diaz de LABANDero, Gaspar: Historia de la guerra civil de Cataluña en la última época, terminada con la emigración a Francia de las tropas carlistas en julio de 1840 (s. i.), Madrid, 1847.

Duloum, l.: "Le "Foreing office" et le rétablissement de la paix dans les Provinces Basques en 1838-1839 d'après les documents du "Public Record office" ", en Pirineos, XXIII, núms. 83-86, Jaca-Zaragoza, 1967 (1969), 297-308.

Estrella Estrella, José Emilio: El pleito dinástico empezado por don Carlos Maria Isidro de Borbón está solucionado en la actualidad, Gráficas Menor, Madrid, 1964.

Fernández Gaytán, J.: "La marina en las guerras carlistas", en Revista General dela Marina, CLX, Madrid, 1961. 
Fernández de los Ríos, A.: Estudio histórico de las luchas políticas en la España del siglo XIX (s. i.), 1879.

Ferrer, Melchor: Historia del tradicionalismo español. Tomo XVIII: Desde la terminación de la Guerra de los Siete Años, en 1840, hasta la abdicación de Carlos V, en 1845. Tomo XIX: Carlos VI. Desde la abdicación de Carlos $V$, en 1845, hasta el fin de la guerra de los Matiners, en mayo de 1849. Tomo XX: Desde el final de la guerra de los Matiners, en 1849, hasta la terminación de la campaña montemolinista de 1855-56. Ed. Católica Española, S. A., Sevilla, 1957.

- Breve Historia del legitimismo español, ed. Montejurra (vol.1), Madrid, 1958.

FonfRÈDE, Henri: De la Révolution espagnole depuis la mort de Ferdinand VII jusqu'à l'abdication de Marie Cristine, 2. a ed., Burdeos, 1848.

Galindo Herrero, Santiago: Breve historia del tradicionalismo español, Publicaciones españolas (El libro para todos, 3), Madrid, 1956.

Goeben, Augusto von: Cuatro años en España (1836-1840). Los carlistas. Su levantamiento, su lucha y su ocaso. Esbozos y recuerdos de la guerra civil. Prólogo, traducción y notas de Luis Ruiz Hemández. Inst. Príncipe de Viana, Diputación Foral de Navarra, Pamplona, 1966.

Gorricho Moreno, Julio: "El pretendiente Carlos V y el papa Gregorio XVI", en Anthologia Annua, X, Roma, 1962.

Gracera y Castillo, José: «Don Sancho Conejo y Bejarano. Un carlista de tierras liberales", en Hidalguía, XIV, núm. 76, Madrid, 1966, 295-302.

HARDMAN, Frederick: La guerra carlista vista por un inglés. Traducción, selección y prólogo de Jesús Pardo. Ed. Taurus (Temas de España, 65), Madrid, 1967.

HARPER, Glenn Terry: "The Spanish Diary of Artur Middleton", en Southern Quarterly, VII, núm. 3, 1969, 207-250.

Henningsen, C. F.: Zumalacárregui. Campaña de doce meses por las provincias vascongadas y Navarra, 2. ed., Buenos Aires, 1947.

Hobsbawm, E. J.: Rebeldes primitivos, Ed. Ariel, Barcelona, 1968.

IDOATE, Florencio: «Relación del viaje del Rey y Señor Don Carlos V de Bayona a Elizondo en 1834, según Joaquín Da Cruz», en Príncipe de Viana, XXIII, números 88-89, Pamplona, 1962. 
INSAUSTI, Sebastián: "Jurisdicción eclesiástica delegada en territorio carlista (1836-1839)", en Scriptorium Victoriense, XIII, núms. 1-2, Vitoria, $1965,212-230$.

Iribarren, J. M.: "Sentido y origen de la voz "requeté" ", en Príncipe de Viana, XX, núms. 76-77, Pamplona, 1959.

IZAGUIRRE, Fernando: "Aragón en la primera guerra carlista: el Barón de Hervés". J. Zurita, Cuadernos de Historia, VI-VII, Zaragoza, 1954 (1958), 93-119.

Jiménez LozANo, José: "El cura Merino a uña de caballo", en Historia y Vida, I, núm. 5, Barcelona-Madrid, 1968.

Leemings, J. S.: "George Villiers, British ambassador at Madrid (1835-38) with special reference to Anglo-french relations and British Auxiliary Legion", en Bulletin of the Institute of Historical Research, XXXVII, núm. 95, Londres, 1964.

LASSALA, M.: Historia política del partido carlista (s. i.), 1841.

LICNOWsky, Manuel: Recuerdos de la guerra carlista, Madrid, 1942.

López Aranguren, José Luis: "Aragón en la primera guerra carlista». J. Zurita, Cuadernos, VI, Zaragoza, 1958.

Lladonosa, Josep: La primera guerra carlina a les terres de Lleida, Rafael Dalmau, editor (Episodis de la Historia, 73), Barcelona, 1966.

LLUIS y NAVAS, Jaime: "Las divisiones-internas del carlismo a través de la historia. Ensayo sobre su razón de ser (1814-1836)", en Homenaje a V. Vives, II, Barcelona, 1967, 307-345.

MadRazo, Francisco de Paula: Historia militar y política de Zumalacárregui $y$ de los sucesos de la guerra de las provincias del Norte enlazados a su época y su nombre, Madrid, 1844.

Magin Ferrer: La cuestión dinástica. Examen de las leyes que el gobierno usurpador y las llamadas Cortes de 1834 alegaron para apoyar el derecho de doña Isabel, Madrid, 1864, 345 págs. + VIII.

MaRRERo, Vicente: El tradicionalismo español del siglo XIX. Selección y prólogo de... Dirección General de Información. Publicaciones Españolas (Textos de Doctrina Política, 4), Madrid, 1955.

Martinez de Campos y Serrano, C.: España bélica. Siglo XIX. Aguilar (Col. Panorama de un siglo), Madrid, 1961. 
MenÉndez y Pelayo, Marcelino: La matanza de los frailes, Ed. Lectura (México), CLIX, núm. 2, 1964.

Ochagavia Fernández, Diego: "Abrazos y tiros. Los fusilamientos de Estella y el abrazo de Vergara», en Berceo, XIX, núm. 73, Logroño 1964.

OlcınA, Evarist: El carlismo y las autonomias regionales. Prólogo de T. Benet. Seminarios y Ediciones, Madrid, 1974.

Olivo y Otero, Manuel: Don Carlos María Isidro de Borbón. Historia de una vida militar y política, Madrid, 1844, 3 vols.

Otero Pedrayo, R.: «Algunhas lembranzas e notas de primeira guerra carlista na Galiza e do xefe tradicionalista Mateo Guillade", en Boletín de la Real Academia Gallega, XXVII, núms. 309-320, La Coruña, 1956, 373-379.

Oyarzun, Román: El alavés don Bruno de Villarreal, teniente general carlista, Diputación Foral de Álava, Consejo de Cultura, Vitoria, 1964.

- Historia del carlismo, Ed. Alianza (El libro de bolsillo), Madrid, 1969.

PABón, J.: La otra legitimidad, Ed. Prensa Española, Madrid, 1965.

Pardo Canalis, E.: "En los comienzos de la primera guerra carlista. Una evocación de Fortuny", en Anales del Instituto de Estudios Madrileños, VIII, Madrid, 1872, 395.400.

PIRALA: Historia de la guerra civil y de los partidos liberal y carlista, Ed. Mellado, Madrid, 1868-69, 6 vols.

- Vida y hechos de don Tomás Zumalacárregui, nombrado por el Sr. D. Carlos Maria Isidro de Borbón capitán general del ejército realista, duque de la Victoria y conde de Zumalacárregui, Madrid, 1845.

Pujol Escalé, Francisco de A: "El incendio de Manlleu», en Ausa, I, núm. $10,1952-1954,452-455$.

Redondo, Luis, y Zavala, Juan de: El requeté (la tradición no muere), Ed. AHR (Colección "La epopeya y sus héroes»), Barcelona, 1957.

Revuelta González, M.: "Los conventos de Vizcaya durante la primera guerra carlista", en Letras de Deusto, núm. 7, Bilbao, 1974, 53-86.

Sáenz Garcia, Clemente: "La "noche triste" del general Cabrera", en Celtiberia, XXIV, Soria, 1971, 75-104. 
SagüÉs Azcona, Pío: "Un memorial de don Carlos María Isidro de Borbón sobre la guerra civil española en 1838", en Archivo Ibero-Americano, XXV, núm. 120, Madrid, 1970, 495-512.

SánCHEZ, R.: Historia de don Carlos y de los principales sucesos de la guerra civil española, Madrid, 1844, 2 vols.

San Miguel, Evaristo: De los facciosos, Madrid, 1837.

Sanz Diaz, José: Generales carlistas, II, Publicaciones Españolas (Temas españoles, 228), Madrid, 1956.

- "Los pensadores de la tradición española", en Conmunità Europea, IV, núm. 27, Milán, 1957, 8-10.

Sebastián Ruzz, Fray Agustín: "Otro capítulo oscuro de la biografía del Cura Merino", en Boletín de la I. Fernán-González, XLV, núm. 167, Burgos, 1966, 385-395.

- "Otro capítulo oscuro de la biografía del Cura Merino", en Boletín de la Inst. Fernán-González, XLV, núm. 169, Burgos, 745-757.

Seco Serrano, Carlos: "D. Carlos y el carlismo", en Rev. de la Univ. de Madrid, IV, núm. 13, 1955, 27-51.

- "Semblanza de un rey carlista en las páginas de su diario íntimo", en Rev. de la Univ. de Madrid, XIX, 1956, 339 y sigs.

- Tríptico carlista. Estudios sobre historia del carlismo, Ed. Ariel, Barcelona, 1973.

Silgo Gamero, Juan: "El servicio de sanidad en las guerras carlistas", en Rev. de Historia Militar, XIII, núm. 76, Madrid, 1969, 93-103.

Suárez Verdaguer, Federico: La investigación del siglo XIX español. Fuentes de la historia de España. Bibliografía de las guerras carlistas y de las luchas políticas del siglo XIX, II (IHE, núm. 7.505), 5-24.

Tierno Galván, E.: Tradición y modernismo, Tecnos, S. A. (Col. Semilla y Surco, núm. 25), Madrid, 1962.

Torresano Vázouez, Julián de: Resumen histórico del tradicionalismo político español, Ed. Selección (Col. Volveré), Olesa de Montserrat, 1960.

Viñas Cebrián, Jesús: "Pronunciamiento y asedio de Sevilla. Junio-julio 1843", en Archivo Hispalense, XL, núms. 124-125, Sevilla, 1964. 
WISDOM, Thomas: Estudio histórico-militar de Zumalacárregui y Cabrera. Traducción del inglés. Madrid, 1890.

Yaque Laurel, José: "La expedición carlista del general Gómez en el año 1836", en Revista de Historia Militar, II, núm. 2, Madrid, 1958.

Zaratiegui, J. A.: Vida y hechos de D. Tomás Zumalacárregui, San Sebastián, 1946, 2. ${ }^{\mathrm{a}} \mathrm{ed}$.

ZUMALDE, lgnacio: "Notas sobre la primera guerra carlista", en Boletín de la Real Sociedad Vascongada de los Amigos del País, XVII, núm. 3, San Sebastián, 1965.

\subsection{Movimiento obrero}

Alarcón CARACUel, Manuel R.: El régimen jurídico de la asociación obrera en el derecho histórico español (1839-1900), Publicaciones de la Universidad de Sevilla, 1973.

ARDIT, M.: "Revolución burguesa y revuelta campesina (1789-1840)», en Siete temas sobre historia contemporánea del País Valenciano. Prólogo de J. Manuel Cuenca. Facultad de Filosofía y Letras, Valencia, 1971, 507-527.

BENET, J., Y MARTI, C.: Barcelona a mitjan del segle XIX. El moviment obrer durant el bieni progresista, 1854-1856, Barcelona, 1976.

BenET, Josef: «lldefons Cerdá i el moviment obrer catalá», en Serra d'Or, 2. época, I, n.․ 2-3, Barcelona, 1959.

Bibliografía dels moviments socials a Catalunya, Pais Valenciá i les lles. Dirigida por E. Giralt i Raventós amb la collaboració de A. Balcells, A. Cucó, J. Termes i equip de redacció. Lavinia, Barcelona, 1972.

Borrego, Andrés: La cuestión social considerada en sus relaciones con la historia y las condiciones del carácter del pueblo español. Cómo se ha efectuado la desamortización eclesiástica y civil y cuáles han sido sus consecuencias, El porvenir literario, Madrid, 1881.

- De la situación y de los intereses de España en el movimiento reformador de Europa, 1848, Edición y notas de D. Gómez Molleda, Madrid, 1970.

Caro Baroja, J.: "Costumbres y formas de vida en la España del siglo XIX", en Historia social de España. Siglo XIX, Ed. Guadiana, Madrid, $1972,77-84$. 
Cole, G. D. H.: Historia del pensamiento socialista, tomo II, Fondo de Cultura Económica, México-Buenos Aires, 1957-1960.

Comellas, José Luis: Los movimientos subversivos en la época romántica. Univ. de Santiago de Compostela. Actos de las Primeras Jornadas de Metodología Aplicada de las Ciencias Históricas, 1975.

Сomin Colomer, Eduardo: Historia del anarquismo español, Ed. A. H. R., Barcelona, 1956, 2 vols.

Cores Trasmonte, Baldomero: "Comunidad y sociedad en las ideologías políticas del siglo XIX español", en $B$. de la Univ. Compostelana, LXVIII-LXIX, 1961, 33-51.

Diaz-PLAjA, Fernando: La vida española en el siglo XIX, Prensa Española (Col. "Los tres dados"), Madrid, 1969.

Elorza, A.: "Los orígenes del asociacionismo obrero en España", Revista de Trabajo, n. 37, Madrid, 1972, págs. 123-345.

- El Fourierismo en España, Madrid, 1975.

Flores, Antonio: Ayer, hoy y mañana o la fe, el vapor y la electricidad. Cuadros sociales de 1800, 1850 y 1890, Francisco Álvarez ed., Sevilla, 1981.

Fraga, M.: Las transformaciones de la sociedad española contemporánea, Ediciones del Movimiento (Prensa Gráfica), Madrid, 1959.

GaRRIDo, F.: La Federación y el Socialismo. Selección de textos por J. Maluquer de Motes, Barcelona, 1970.

Giralt, E.; Balcells, A., y Termes, J.: El moviments socials a Catalunya, País Valenciá i les illes. Cronología 1800-1939, Lavinia, S. A., Barcelona, 1967.

JimÉnEz BlanCo, J.: «Estructuración social e ideologia», en Historia social de España, Guadiana, Madrid, 1974, 3541.

Jutglar, A.: Ideologías y clases en la España contemporánea. Aproximación a la historia social, 1808-1874, Edicusa, Madrid, 1968.

- "Notas sobre la evolución de las burguesías españolas en el siglo XIX", en Historia social de España. Siglo XIX, Ed. Guadiana, Madrid, $1972,115-129$.

LAComBA, J. A.: "Estructura demográfica y dinámica social en la España del siglo XIX", en Historia social de España. Siglo XIX, Ed. Guadiana, Madrid, 1972, 45-74. 
LAMBERT, Renée: Mouvements ouvriers et socialistes (Chronologie et bibliographie). Espagne (1750-1936). Prólogo de Edouard Dolléens. Les éditions ouvrieres, Paris, 1953, 204 págs.

LIDA, Clara E.: Antecedentes y desarrollo del movimiento obrero español (1835-1888). Textos y documentos, Siglo XXI de España Editores, Madrid, 1973.

López Aranguren, J. L.: "Moral y sociedad en el siglo XIX", en Historia social de España. Siglo XIX, Ed. Guadiana, Madrid, 1972.

Maluquer de Motes, J.: El Socialismo en España, 1833-1868, Barcelona, 1977.

MARIAS, J.: "La estructura social de España en el siglo XIX", en Historia social de España, Ed. Guadiana, Madrid, 1972, 13-31.

MARTi, Casimiro: «El movimiento obrero en Barcelona durante el bienio progresista (1854-1856)", en Estudios de Historia Social, n. 2-3, juliodic. 1977.

- Orígenes del anarquismo en Barcelona, Barcelona, 1959.

Marti BuflLL, Carlos: Nuevas soluciones al problema migratorio, Cultura Hispánica (Publ. del I. C. Iberoamericano de Cooperación Económica, 2), Madrid, 1955.

Marx, C., y Engels, F.: Revolución en España, Ariel, 4. a ed., 1973.

Mateo del Peral, Diego Ignacio: "Andrés Borrego y el problema de las clases medias", en Revista de Estudios Políticos, núm. 126, Madrid, 1962.

MAURICE, J. (dir.): "Culturas populares y culturas obreras en España, 18401883", en Peuple, mouvement ouvrier, culture dans I'Espagne contemporaine, P.U.V., Saint Denis, 1989.

Oliva Marra-López, Andrés: Andrés Borrego y la política española del siglo XIX, Instituto de Estudios Políticos, Madrid, 1959.

Ollé Romeu, M.: El moviment obrer a Catalunya, 1840-1843. Textos i documents, Nova Terra (El sentir de la Historia, núm. 5), Barcelona, 1973.

PABÓN, Jesús: La subversión contemporánea y otros estudios, Madrid, 1971.

Pérez Ledesma, M.: El obrero consciente, Madrid, 1987. 
Prieto, Fernando: Apuntes históricos del movimiento obrero español, Ed. Zero, Madrid 1973.

Reventós, Manuel: Els moviments socials a Barcelona durante el segle $X I X$, Barcelona, 1925.

Reventós Corner, Juan: El movimiento cooperativo en España. Prólogo de Alberto Pérez Baró, ed. Ariel, Barcelona, 1960.

Rodríguez CASAdo, Vicente: Los cambios sociales y políticos en España e Hispanoamérica, Ed. Nacional (Col. Crece o muere), Madrid, 1955.

Rolg I Fransitorra, Joan: La vaga obrera, Edicions 62 (Col. Llibres a l'Abart, número 98), Barcelona, 1971.

Rubio I Balaguer, Jordi: "La commemoració del 1859", Germinabit, n.․601, Barcelona, 1959, 1-3.

Ruiz I CAlonja, Joan: "Ressons bibliografics barcelonins de les teories societaries", en Homenaje a V. Vives, II (IHE, núm. 64223), 613-619.

SAlom Costa, J.: «El proletariado y las clases populares españolas», en Historia social de España. Siglo XIX, Ed. Guadiana, Madrid, 1972, 149170.

Seco Serrano, Carlos: "La toma de conciencia de la clase obrera y los partidos políticos de la era isabelinan, en La Revolución de 1868. Historia. Pensamiento. Literatura. Selección de Clara E. Lida e Iris M. Zavala. Prólogo de V. Llorens. Las Américas Publishing Company, Nueva York, 1970, 25-47.

- Sociedad, liferatura y politica en la España del siglo XIX, Biblioteca Universitaria Guadiana, Guadiana de Publicaciones, Madrid, 1973.

Sociedad, política y cultura en la España de los siglos XIX y XX (Coloquio del Seminario de Estudios de los siglos XLX y XX, Universidad de Pau). M. Tuñón de Lara, Joaquín del Moral, Teresa Rodríguez de Lecea... (y otros), Edicusa, Madrid, 1973.

Sola Cañizares, F. de: Luchas sociales en Cataluña, 1812-1934. Prólogo de A. Gallart i Folch, Zero, S. A. (Col. Zero, Serie R, 11), Algorta, 1970.

TERÁN, Manuel de: "La inmigración política española en el centro de Aquitania en el siglo XIX", en Estudios Geográficos, XX, núm. 75, Madrid, 1959.

TERRÓN, Eloy: Sociedad e ideología en los origenes de la España contemporánea, Ed. Península, Barcelona, 1969. 
Trías, J. J., y Elorza, A.: Federalismo y reforma social en España (18401870), Madrid, 1975.

Trujilo Fernández, G.: Pi y Margall y los orígenes del Federalismo español. Ed. Tecnos, Madrid, 1955.

\subsection{Ejército}

Acevedo SÁnchez, Emilio: Memoria histórica de la Milicia Nacional con expresión de algunos hechos realizados por la misma, Tip. de la Bolsa, Madrid, 1905.

Aguado Sánchez, Francisco: "Síntesis histórica del cuerpo de carabineros", en Revista de Estudios Históricos de la Guardia Civil, VI, núm. 11, Madrid, 1973, 9-48.

Alonso, José Ramón: Historia política del ejército español, Ed. Nacional, Madrid, 1974.

Borao, Jimeno: Historia del alzamiento de Zaragoza en 1854, por D..., Santiago Ballés, Zaragoza, 1855.

Busouets Bragulat, Julio: "La sociologia militar en España", en Revista de Estudios Políticos, núm. 158, Madrid, 1968, 169-184.

- "Los militares y la sociedad decimonónica", en Historia social de España. Siglo XIX, Ed. Guadiana, Madrid, 1972, 207-228.

- "Los pronunciamientos militares en España", en Revista del Inst. de Ciencias Sociales, núm. 11, Barcelona, 1968, 53-72.

Cardona, G.: El poder militar en la España contemporánea hasta la Guerra Civil, Madrid, 1983.

CASTILLO, Rafael del: Historia de la vida militar y política del señor don Leopoldo O'Donnell, Jesús Garcia (Cádiz, Imp. de la Rev. Médica), Madrid, 1860.

Comellas, José Luis: Los primeros pronunciamientos en España, CSIC, Escuela de Historia Moderna, 1954.

ChristIANSEN, Erick: The origins of military power in Spain, 1800-1854, Oxford University Press, Londres, 1967. Edición española: Trad. de Luis Escolar Bareño. Prólogo de José Fortes Bouzán, Aguilar, Madrid, 1974. 
Espadas Burgos, Manuel: La Milicia Nacional, Inst. de Estudios Madrileños (Aula de Cultura, 4), Madrid, 1972.

Fernández Bastarreche, Fernando: El ejército español en el $S$. XIX. Siglo XXI España editores, Madrid, 1978.

Fernández de Córdova, Fernando: Memoria justificativa que dirige a sus conciudadanos el general Córdoba en vinculación de los cargos que se han hecho o del conducto... en el asunto de los ejércitos..., T. Jordán, Madrid, 1837.

- Mis memorias intimas..., Ed. y estudio preliminar por M. Artola Gallego, Atlas, Madrid, 1966, 2 vols.

Forsa política o llámese pronunciamiento, melomimo-drama-pantomímico-político-burlesco, original en nueve cuadros y en verso. Representado en julio de 1843. Composición satírica por J. M. P., J. Aguado, Madrid, 1843.

Fuerzas Armadas Españolas (varios autores), ed. Alhambra, Tomos III y IV, Madrid, 1986.

López Garrido, D.: La Guardia Civil y los origenes del Estado centralista, Barcelona, 1982.

LLABRES, Juan: "El transporte de guerra "Malaspina" y su naufragio (18591867)", en Revista General de Marina, CLVII, Madrid, 1959.

Martinez Ruiz, E.: Creación de la Guardia Civil, Madrid, 1977.

- "Las fuerzas de seguridad y orden público en la primera mitad del siglo XIX", en Estudios sobre la España liberal, CSIC, Madrid, 1973, 83161.

Pabón y SuÁrez de URBina, Jesús: El régimen de los generales desde una fecha $y$ un archivo, Instituto de España, Imp. y Ed. Maestre, Madrid, 1968.

Payne, Stanley G.: Politics and the Military in Modern Spain, Stanford University Press, Stanford, 1967.

- "El ejército entre el caos progresista y la reacción conservadora". Artículo en Historia y Vida, n. 3, 1974.

Pérez Garzón, Juan Sisinio: Milicia Nacional y revolución burguesa. El prototipo madrileño, 1808-1874. Prólogo de Manuel Espadas Burgos, I. Jerónimo Zurita, CSIC, Madrid, 1978. 
SalAS, Fernando de: Literatura militar, Madrid, 1954.

- Escritores militares contemporáneos. Ed. Nacional, Madrid, 1967.

Tierno Galván, E.: "La conspiración, fenómeno decimonónico", en Historia social de España. Siglo XIX, Ed. Guadiana, Madrid, 1972, 229-240.

\subsection{Iglesia}

BARTLET, C. J.: "The question of religious tolerations in Spain in the nineteenth century", en Journal of Ecclesiastical History, VIII, núm. 2, Londres, 1957, 205-216.

BECKER, Jerónimo: Relaciones diplomáticas entre España y la Santa Sede durante el siglo XIX, Jaime Ratés, Madrid, 1908.

- "España y la Santa Sede. Sus relaciones durante el reinado de Isabel II», en España Moderna, CCXXIV, 1906, 5-31.

BotreL, J. M.: La iglesia católica y los medios de comunicación impresos en España de 1847 a 1917, ed. S. XXI, Madrid, 1982.

Cambronero, Carlos: "La matanza de frailes el año 1834, según documentos inéditos del Archivo Municipal", en Revista Contemporánea, CVII, 1897, 98-103.

Canals VIDAL, Francisco: Cristianismo y revolución. Los orígenes románticos del cristianismo de izquierda, Ed. Acervo, Barcelona, 1957.

CANGa Argüelles, José: El gobierno español en sus relaciones con la Santa Sede, Colección de documentos publicados antes y después del rompimiento de sus relaciones, Madrid, 1856.

Cárcel Ortí, Vicente: «El primer documento colectivo del Episcopado español. Carta al Papa en 1839 sobre la situación nacional», en Scriptorium Victoriense, XXI, Vitoria, 1974, 152-199.

- Historia de la Iglesia en España, t. V, Biblioteca de Autores Cristianos, Madrid, 1979.

- Política eclesial de los gobiernos españoles (1830-1840), EUNSA, Pamplona, 1975. 
CASTILlo y AYENSA, José del: Historia crítica de las negociaciones con Roma desde la muerte del Rey Don Fernando VII, Imp. Tejado, Madrid, 1859, 2 vols.

Colección completa de Concordatos españoles, por don Juan Tejada y Ramiro. Concordato de 1851, Imp. de Pedro Montero, Madrid, 1862.

Cuenca ToriBio, J. M.: «El catolicismo liberal español: las razones de una ausencia", en Archivo Hispalense, LV, núm. 169, Sevilla, 1972, 53-62.

- "Iglesia y Estado en la España contemporánea (1789-1914)», en lus Canonicum, X, Pamplona, 1970, 405-455.

- La Iglesia española ante la revolución liberal, Ediciones Rialp, S. A., Madrid, 1971.

- "La tercera restauración religiosa del siglo XIX. Contribución a la historia de la iglesia sevillana contemporánean, en Anales de la Universidad Hispalense, XXVII, Sevilla, 1966, 1-11.

- Apertura e integrismo en la Iglesia española decimonónica, Sevilla, 1970.

- Sociedad y clero en la España del XIX, Córdoba, 1980.

Désfourneaux, Marcelin: "Les dernières annnées de l'Inquisition espagnole, 1814-1820-1834", en Annales Historiques de la Revolution Française, núm. 2, París, 1963, 161-184.

Disertación canónica... sobre jurisdicción de la lglesia... la dedica... el L. D. J. M. de N., Norberto Llorenci, Madrid, 1842.

Garcia Rives, Luis: «El Archivo-Biblioteca del Ministerio de Asuntos Exteriores", en Boletín General de Archivos y Bibliotecas, XII, núms. 72-73, Madrid, 1965, 25.

Gorricho, Julio: "Relación de la fuga, prisión y destierro del obispo de Palencia (1835-1837)", en Scriptorium Victoriense, XVIII, núm. 3, Vitoria, $1971,326-344$.

IzAguirRe IrURETA, Fernando: "Las relaciones diplomáticas de la Santa Sede con el Gobierno español durante la primera guerra carlistan, en Universidad, XXXV, núm. 34, Zaragoza, 1958.

Juicio imparcial sobre los bienes eclesiásticos que dedica al venerable clero español D. J. L. G., J. Sanz, Madrid, 1841. 
La Hera, Alberto de: "La situación jurídica de los no católicos en España (1812-1936)", en Revista del Inst. de Historia del Derecho Ricardo Levene, núm. 21, Buenos Aires, 1970, 200-209.

Legarda, P. Anselmo de: "Desahogos cristianos en 1835", en Boletín de la Real Sociedad Vascongada de Amigos del País, IX, 1953, 203-209.

Longares, J.: Política y Religión en Barcelona (1833-1843), Madrid, 1977.

LUNA, Pedro de: "A crucial period for the Spanish Church", en Ibérica, XXII, núm. 5, 1964, 7-10.

Martín Martínez, Isidoro: Eclesiásticos en organismos políticos españoles, Fundación Universitaria Española, Madrid, 1973.

Romo, Judas José, obispo de Canarias: Independencia constante de la Iglesia hispana y necesidad de un nuevo Concordato, 2. ed., Madrid, 1843.

Rosenblatt, Nancy A.: "The Spanish Moderados and the Church, 18341835", en The Catholical Historical Review, LVII, Washington, 1971$1972,401-420$.

Serrano, Luciano: Correspondencia diplomática entre España y la Santa Sede, Madrid, 1914, 2 vols.

SuÁrez, Federico: "Génesis del Concordato de 1851". Ius Canonicum, III, n. 1-2, Pamplona, 1963.

\section{ESTUDIOS REGIONALES}

Aizpún Santafé, Rafael: "Naturaleza jurídica de las leyes forales de Navarra", en Príncipe de Viana, XIII, 1952.

Azagra Ros, J.: El bienio progresista en Valencia. Análisis de una situación revolucionaria a mediados del siglo XIX (1854-1856), Valencia, 1978.

Bacon, Francisco: Historia de la revolución de las provincias Vascongadas y Navarra desde 1833 al 1837, con una reseña politica y religiosa de España, Editorial Txertoa, San Sebastián, 1973.

BATTISTA I RocA, J. M. ․: "The Junta of Catalonia from August to October 1835", en The Anglo-Catalan Society thiral Conference Refort, Cambridge, 1957. 
Carrera PujaL, Jaime: Historia política de Cataluña en el siglo XIX, Bosch Casa Editorial, Barcelona, 1957, 4 vols.

Estevan Senis, M." Teresa: "La minería cartagenera, 1840-1919. Aspectos económicos y sociales». Hispania, 101, 1966, págs. 61-95.

Fernández Clemente, Eloy: "Aragón contemporáneo (1833-1936)", en Estudios de Historia contemporánea, Siglo XXI de España editores, S. A., Madrid, 1975.

Fernández Garcia, Antonio: El abastecimiento de Madrid en el Reinado de Isabel II. Prólogo de V. P. Atard, Instituto de Estudios Madrileños, CSIC, Madrid, 1971.

Ferrer, Antoni: Compendi d'historia de Catalunya ( $6 . X I X)$, Bruguera (Quadern de Cultura, 35), Barcelona, 1967.

Garcia Barros, Jorge: Medio siglo de vida coruñesa, 1834-1886. Del miriñaque al tren veloz, Grafinsa, La Coruña, 1970.

Garcia Fernández, Jesús: «El ferrocarril Zamora-La Coruña». Estudios Geográficos, XVIII, n.ำ 69, Madrid, 1957.

Garcia Montoro, C.: Málaga en los comienzos de la industrialización. Manuel Agustín de Heredia, 1786-1846, Córdoba, 1978.

GaRRABOU, R.: Engynyers industrials, modernisation económica e burguesia a Catalunya, Barcelona, 1982.

Gascón Pelegri, V.: La Revolución del 68 en Valencia y su reino, Castellón, 1975.

Gil Novales, A.: La Revolución de 1868 en el Alto Aragón, Zaragoza, 1980.

Gómez Iglesias, Agustín: "Causas decisivas e incidencias de la demarcación territorial de Madrid realizada en 1822-1841", en Anales del Inst. de Estudios Madrileños, V, 1970, 355-376.

HIDALGO, Jacinto: "El Ayuntamiento de Madrid y el jefe político (1813-38)", en Revista de la Biblioteca, Archivo y Museo del Ayuntamiento de Madrid, XXIII, núm. 68, 1954, 295-328.

IribarRen, J. M.a: Vitoria y los viajeros del siglo romántico. Pub. de la obra cultural CAMP de la ciudad de Vitoria, Vitoria, 1950.

Jiménez-Land, Antonio: Esos días..., Aguilar, Madrid, 1965. 
JURETSCHKE, Hans: "Del romanticismo liberal en Cataluña», en Revista de Literatura, VI, núms. 11-12, 1954, 9-30.

Los primeros cien años del Canal de Isabel II. Canal de Isabel II, Madrid, 1954.

Llabrés, Juan: Noticias y relaciones históricas de Mallorca (1801-1850), t. II, Anejo de Boletín de la Sociedad Arqueológica Luliana, Palma de Mallorca, 1862.

OJEDA, G.: Asturias en la industrialización española, 1833-1907. Ed. S. XXI, Madrid, 1985.

Otero Pedrayo, R.: «Las polémicas sobre los diezmos en Galicia a principios del siglo XIX", en Cuadernos de Estudios Gallegos, X, núm. 32, Santiago de Compostela, 1955, 435-438.

Ortega Canadell, Rosa: "La crisis política española de 1832-1833. La opinión pública en Barcelonan, en Estudios de Historia moderna, V, Barcelona, 1955 [1957].

Ramirez de las Casas-Deza, Luis M.ạ: "Anales de la ciudad de Córdoba", en Boletín de la Real Academia de Córdoba, XXIII, núm. 68, 1952, 289310.

Ramos VIDAL, Juan Antonio: Orihuela bajo la Regencia de Maria Cristina de Borbón (1833-1840), Publ. de la Obra Cultural de la Caja de Ahorros de Nuestra Señora de Monserrate, Murcia, 1974.

Rodriguez GarRazA, R.: Navarra, de reino a provincia (1828-1841), Universidad de Navarra (Col. "Histórica», XXI), Pamplona, 1968.

Rozalejo, Marqués de: Cheste o todo un siglo (1809-1906), el isabelino tradicionalista, Espasa-Calpe, Madrid, 1935.

Sirere, Monique: "La colonie espagnole de Perpignan", en Cerca, núm. $23,1964,81-89$.

Solis LloREnTE, Ramón: "Cádiz en la España del siglo XIX", en Cádiz, adelantada del siglo XIX, Gobierno Militar, Aula Militar de Cultura, Cádiz, 1965.

Tettamanc y Gastón, Fco.: La revolución gallega de 1846, Carré, La Coruña, 1908.

Un segle de vida catalana (1814-1930), Alcides, Barcelona, 1961.

UrouiJo y GoITIA, J. R.: La Revolución de 1854 en Madrid, Madrid, 1984. 
VARela JaCome, Benito: "Una publicación pontevedresa en 1849". El Museo de Pontevedra, VII, n.. 25-26, 1952, 27-33.

VICENS I VIVES, Jaume: Els catalans en el segle XIX, Ed. Teide, Barcelona, 1958.

Vilarrubia Garet, Conrado: "Curioseando por nuestras payesias", en Calendario del payés, I, Agrícola Catalán de P. Isidro, págs. 161-164.

VOLTES, Pedro: "Documentos de tema español existentes en el Archivo del Estado de Bremen", en Cuadernos de historia económica de Cataluña, V, 1971, 81-93. 